\title{
Study of Evaluation Machinability of a Stainless Steels and Accompanying Phenomena in the Cutting Zone During Machining
}

\author{
Jozef Jurko ${ }^{1}$, Anton Panda ${ }^{1}$ and Tadeusz Zaborowski ${ }^{2}$ \\ ${ }^{1}$ Technical University of Košice, \\ 2IBEN Wlkp \\ ${ }^{1}$ Slovak Republic \\ 2Poland
}

\section{Introduction}

The production process - cutting process (working materials) is currently still one of the fundamental technologies of production parts. It is therefore necessary that the cutting process was effective, the products are competitive mainly in terms of production costs. If we consider the technological system M-machine, T-tool, W-workpiece and F-fixture, each element of this system has a different percentage of production costs. But the most important reason for the need of productive machining production time is that it is necessary to always use the best. This is a guide to success for a large part of production processes, ie maximum number of products per unit of time. Especially during operation, for variations in technological progress in production, there are significant changes in the cost per piece produced parts. Currently we can apply several alternatives for increasing productivity cutting process:

a. Alternative: Investment in new $\mathrm{CNC}$ machine to ensure the production program is especially important that this machine can significantly increase performance and speed aside, to improve the conditions of production and thereby ensuring returns in the coming years, and profit.

b. Alternatives: Improving the cutting process is a way of improving the cutting process continuously, provided the correct application of cutting tools - for defined machining conditions and for a defined set of M-F-W technology. In comparison with a) this solution is inexpensive (compared to the price of a new machine).

Developments in the machining method is dynamic and applied a decade or five years ago are largely already non-progressive. Seeing similar developments in the production of advanced cutting tools (for a defined structure for the defined basic materials for defined surface layer). On this basis, it is possible to achieve a productive day as production. one operating the machine, especially the change of applied cutting tools. Non-use benefits of development and inability to correct application of advanced cutting tools may be one outcome, namely: untapped potential for increasing its profits and competitiveness. Nature of the cutting process is that there is a complete plastic deformation separated workpiece 
(chip-form) by interaction T (cutting tool) and W (workpiece), defined in terms of a defined technological system M-F. Application of advanced cutting tools to be mainly in terms of economy: faster return on investment (new machinery), improve performance (old machine) and labor productivity service. Currently one of the cost items, which affects the production costs for 1 piece parts is heading: the cost of cutting tool. Every company in the total cost to produce one piece of different components defines the percentage of the cost of cutting tool. Although the costs of cutting tool, the proportion of the total cost to produce one piece of a few parts percentage, have a significant impact mainly on:

1. Cutting process - interaction (cutting tool-workpiece) - impact on the overall result (damage, surface roughness, defects, errors, change in mechanical properties), machined surfaces of the parts.

2. Hours of downtime of the machine - damaged cutting tool (its durability, respectively life, to ensure logistics system - storage, maintenance, service.

3. The number of necessary operations - change in technological progress, quality progressive tool can provide cost savings (production of precise holes - drilling, reaming).

4. Time, which parts must remain in the company.

5. Number of cutting tools, which must be available (logistics, availability).

At the cost mainly affects: labor, machinery, tooling, material, overhead and savings. Automated production of, in the sense of, machine production has characteristic features: a reduction of production costs, stimulation of the development of cutting tools, and changes in the construction of machine tools, all of which work against the creation of optimal technological methods, which thrusts the technological process of cutting into a more important position. These trends confirm that the cutting process remains one of the basic manufacturing technologies. A condition of the economic usage of modern, automated programmed machines is the optimal course of the cutting process, i.e. the use of optimal work conditions. A summary of optimal work conditions requires knowledge of the laws of cutting theory and knowledge of the practical conditions of their application.

\section{Stainless steels}

Stainless steels are distinguished by many features, including:

- inherent resistance to corrosion and heat under given conditions,

- $\quad$ aesthetic factors, hygienic characteristics, ease of cleaning and sterilization,

- a high ratio of strength to weight,

- low magnetic permeability.

Stainless steels are fundamentally subdivided by their chemical composition and metallographic structure. Austenitic steels are the most extensive and thus the most important category of stainless steels. Several kinds of these steels are known, which differ among themselves in their carbon, nickel, and sometimes in their titanium content. Titanium is an important element, which increases the steel's resistance to intercrystalline corrosion.

Current developments in stainless steels is divided into three directions:

1. Development of several species containing up to $0.02 \%$ carbon

2. Development of new types of nitrogen added as an effective alloying elements

3. Development of steel with a further increase in the level of corrosion resistance. 
The basic chemical elements of austenitic steels are resistant to high temperatures and loads chromium-nickel-chromium and nickel. To increase the added resistant to high temperatures and loads tungsten- $\mathrm{W}$ (about $2 \%$ ), molybdenum, Mo (1-3\%), ever-Nb niobium, titanium $\mathrm{Ti}$, vanadium V, N-nitrogen. Chromium content varies from 12 to $20 \%$. Chromium belongs to the group the ferrite formed elements to completely conclude the gamma region. In a purely binary system of iron (Fe) - chromium $(\mathrm{Cr})$ achieves homogeneous area of gamma at $1075^{\circ} \mathrm{C}$ up to $10.6 \%$ chromium content. In technical alloys may be limits to move to higher chromium content, because it had a small amount of carbon and nitrogen gamma significantly expand the area. At high content of $\mathrm{Cr}$ in the binary system $\mathrm{Fe}-\mathrm{Cr}$ appears fragile intermediate sigma phase with variable composition and hardness about $100 \mathrm{HV}$, which is stable up to temperatures of $815^{\circ} \mathrm{C}$. When cooling is falling apart at $460^{\circ} \mathrm{C}$ eutectoid response to a phase $\alpha, \alpha^{\prime}$ the solid solution of Fe - Cr with higher iron content and higher content of chromium. Today, most assumed that the fragility of the high-chromium steels causes the coexistence of these phases, and not the sigma phase. The nickel content is higher than in austenitic steels 18/9, it must obalance the impact the ferrite formed elements and avoid elimination phase which reduces impact strength. For alloys Fe-Ni could be envisaged with a large thermal hysteresis. For a content of about $7 \%$ nickel austenite transformation takes place even under normal conditions of cooling (especially the cooling rate) free diffusion, ie sliding mechanism similar to alloys of iron and manganese. According by Lavesa $\mathrm{Fe}_{2} \mathrm{Mo}$ phase. $\sigma$ Molybdenum increases resistant to high temperatures and loads, however, supports the formation of undesirable phases and Vanadium increases the stress-rupture, especially at lower temperatures. At $700^{\circ} \mathrm{C}$ has little influence vanadium. The additive is especially effective in the presence of nitrogen, since the dislocation creep precipitated vanadium nitrides, whose gross even after long soaking at a temperature only slightly. Carbon inhibits secretion of delta ferrite and increases the mechanical properties. If it is excluded in the basic matrix precipitates as $\mathrm{M}_{23}(\mathrm{C}, \mathrm{N})_{6}$, or $\mathrm{M}_{23}(\mathrm{C}, \mathrm{B})_{6}$, slows the flow. In an unstable steels inhibits formation of sigma phase, which is produced only when the greater part is excreted as carbon carbide. Carbon suppresses the formation phase $\mathrm{Fe}_{18} \mathrm{Cr}_{6} \mathrm{Mo}$ or chi $(\mathrm{Fe}, \mathrm{Ni})_{18} \mathrm{Cr}_{9} \mathrm{Mo}_{4}$. Some Heat resistant austenitic steel containing a small amount of niobium or titanium with carbon are stable carbide. The highest stress-rupture of steel to the ratio Ti/C from 0.8 to 1.2 . Similarly affects resistant to high temperatures and loads niobium, the optimal ratio $\mathrm{nNb}: \mathrm{NC}$ is lower and more dependent on test temperature and time. The disadvantage of steel with niobium is their tendency to crack in the weld area and a decrease in toughness after long lasting working temperature. To increase the yield strength of hot, ultimate strength, respectively. stressrupture is added to austenitic steels unstabilised small amounts of nitrogen, which slows down the diffusion rate of carbon and thus the elimination of coagulation and carbides $\mathrm{M}_{23} \mathrm{C}_{6}$ and other intermetallic phases. Because at the same time reduces the rate of substitutional alloying elements in grain boundaries, extended incubation period of precipitation. Solubility of nitrogen in the steel matrix with a maximum of $0.003 \% \mathrm{C}$ at $1150{ }^{\circ} \mathrm{C}$ is about $0.30 \%$ at 600 to $650{ }^{\circ} \mathrm{C}$ decreases to $0.005 \%$. Admixture of nitrogen to $0.14 \%$ increases resistant to high temperatures and loadsaustenitic steels containing up to $0.03 \%$ as well, that their properties aligned carbon steel containing 0.06 to $0.09 \%$.

\subsection{Categories of stainless steels}

Austenitic-A family of alloys containing chromium and nickel (and manganese and nitrogen when nickel levels are reduced), generally built around the type 302 chemistry of $18 \% \mathrm{Cr}$, $8 \% \mathrm{Ni}$, and balance mostly Fe. These alloys are not hardenable by heat treatment. 
Ferritic - This group of alloys generally containing only chromium, with the balance mostly $\mathrm{Fe}$, are based upon the type 430 composition of $17 \% \mathrm{Cr}$. These alloys are somewhat less ductile than the austenitic types and again are not hardenable by heat treatment.

Martensitic - The members of this family of stainless steels may be hardened and tempered just like alloy steels. Their basic building block is type 410 which consists of $12 \% \mathrm{Cr}, 0.12 \%$ $\mathrm{C}$, and balance mostly Fe.

Precipitation-Hardening - These alloys generally contain $\mathrm{Cr}$ and less than $8 \% \mathrm{Ni}$, with other elements in small amounts. As the name implies, they are hardenable by heat treatment.

Duplex - This is a stainless steel alloy group, or family, with two distinct microstructure phases, ferrite and austenite. The Duplex alloys have greater resistance to chloride stress corrosion cracking and higher strength than the other austenitic or ferritic grades. Classification of stainless steels defines also diagram on base equivalent $\mathrm{Ni}$ and $\mathrm{Cr}$ by Fig.1. Equations 1 and 2 described of equivalent $\mathrm{Ni}$ and $\mathrm{Cr}$.

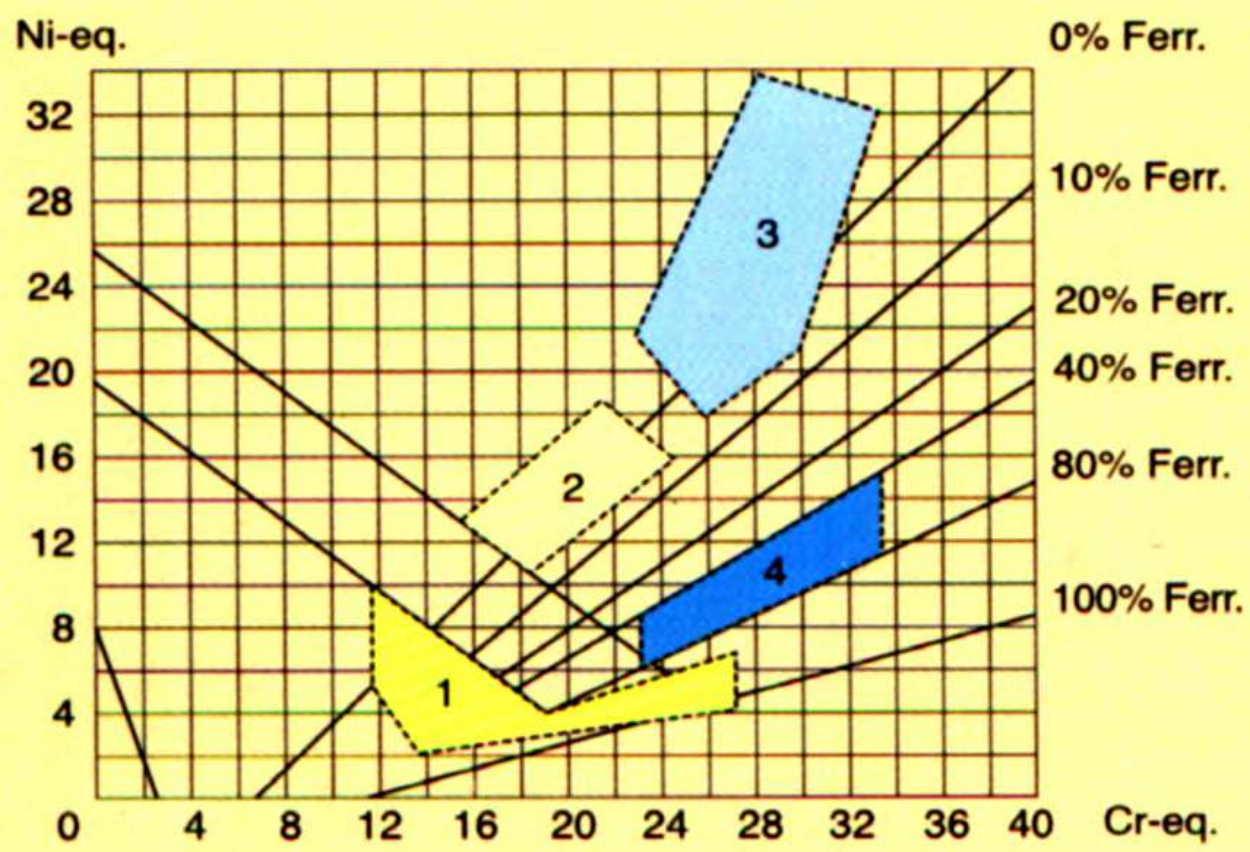

Fig. 1. Schäeffler diagram for Stainless steels, zone 1-structure ferrite, martenzite, zone 2structure duplex (austenite, ferrite), zone 3-structure austenite, zone 4-structure ferrite

$$
\begin{gathered}
\mathrm{E}_{\mathrm{Ni}}=\% \mathrm{Ni}+30 \mathrm{x} \% \mathrm{C}+0,5 \mathrm{x} \% \mathrm{Mn} \\
\mathrm{E}_{\mathrm{Cr}}=\% \mathrm{Cr}+\% \mathrm{Mo}+1,5 \mathrm{x} \% \mathrm{Si}+0,5 \mathrm{x} \% \mathrm{Nb}
\end{gathered}
$$

In Table 1 are mentioned mostly applied stainless steels. 


\begin{tabular}{|c|c|c|c|c|c|c|c|c|c|}
\hline Alloy & $\mathrm{C}$ & Mn & $\mathbf{P}$ & $S$ & Si & $\mathrm{Cr}$ & $\mathrm{Ni}$ & Mo & Others \\
\hline 301 & 0.15 & 2.00 & 0.045 & 0.030 & 1.00 & 17.00 & 7.00 & - & - \\
\hline 302 & 0.15 & 2.00 & 0.045 & 0.030 & 1.00 & 18.00 & 9.00 & - & - \\
\hline 303 & 0.15 & 2.00 & 0.20 & 0.15 & 1.00 & 18.00 & 9.00 & 0.60 & - \\
\hline 303Se & 0.15 & 2.00 & 0.20 & 0.06 & 1.00 & 18.00 & 9.00 & 0.60 & 0.15 Se \\
\hline 304 & 0.08 & 2.00 & 0.045 & 0.030 & 1.00 & 19.00 & 9.25 & - & - \\
\hline $304 \mathrm{~L}$ & 0.03 & 2.00 & 0.045 & 0.030 & 1.00 & 19.00 & 10.0 & - & - \\
\hline 3095 & 0.08 & 2.00 & 0.045 & 0.030 & 0.75 & 23.00 & 13.5 & - & - \\
\hline $310 \mathrm{~S}$ & 0.08 & 2.00 & 0.045 & 0.030 & 1.50 & 25.00 & 20.5 & - & - \\
\hline 316 & 0.08 & 2.00 & 0.045 & 0.030 & 1.00 & 17.00 & 12.0 & 2.5 & - \\
\hline $316 \mathrm{~L}$ & 0.03 & 2.00 & 0.045 & 0.030 & 1.00 & 17.00 & 12.0 & 2.5 & - \\
\hline 317 & 0.08 & 2.00 & 0.045 & 0.030 & 1.00 & 19.00 & 13.0 & 3.5 & - \\
\hline $317 \mathrm{~L}$ & 0.03 & 2.00 & 0.045 & 0.030 & 1.00 & 19.00 & 13.0 & 3.5 & - \\
\hline 321 & 0.08 & 2.00 & 0.045 & 0.030 & 1.00 & 18.00 & 10.5 & - & Ti $5 \times C$ \\
\hline 329 & 0.10 & 2.00 & 0.045 & 0.030 & 1.00 & 27.50 & 4.5 & 1.50 & - \\
\hline 347 & 0.08 & 2.00 & 0.045 & 0.030 & 1.00 & 18.00 & 11.0 & - & $\mathrm{Cb}+\mathrm{Ta} 10 \times \mathrm{C}$ \\
\hline 409 & 0.08 & 1.00 & 0.045 & 0.045 & 1.00 & 11.50 & - & - & $\mathrm{Ti} 6 \times \mathrm{C}$ \\
\hline 410 & 0.15 & 1.00 & 0.040 & 0.030 & 1.00 & 12.50 & - & - & - \\
\hline 416 & 0.15 & 1.25 & 0.040 & - & 1.00 & 13.00 & - & 0.60 & $\mathrm{~S}=0.15 \mathrm{~min}$ \\
\hline 416Se & 0.15 & 1.25 & 0.060 & 0.060 & 1.00 & 13.00 & - & - & $0.15 \mathrm{Se}$ \\
\hline 420 & $0.15 \mathrm{~min}$. & 1.00 & 0.040 & 0.030 & 1.00 & 13.00 & - & - & - \\
\hline 430 & 0.12 & 1.00 & 0.040 & 0.030 & 1.00 & 17.00 & - & - & - \\
\hline $440 \mathrm{C}$ & 1.00 & 1.00 & 0.040 & 0.030 & 1.00 & 17.00 & - & - & - \\
\hline $904 \mathrm{~L}$ & 0.02 & 2.00 & 0.045 & 0.035 & 1.00 & 21.00 & 25.5 & 4.5 & $\mathrm{Cu} 1.5$ \\
\hline $17-4 \mathrm{PH}$ & 0.07 & 1.00 & 0.045 & 0.035 & 1.00 & 16.5 & 5.5 & - & $\mathrm{Cu} 3-5,0.4 \mathrm{Al}$ \\
\hline $17-7 \mathrm{PH}$ & 0.09 & 1.00 & 0.045 & 0.035 & 1.00 & 17.0 & 7.0 & - & $0.75-1.5 \mathrm{Al}$ \\
\hline
\end{tabular}

Table 1. Chemical composition of the Stainless steels

\section{Machining of stainless steels}

Austenitic stainless steels are produced with graded carbon content. The content of chromium steels in this group of about $18 \%$ nickel content is tailored to the requirement that the steel structure was largely austenite. Minor phases present in the structure are made of ferrite and carbides of chromium $\delta$ mainly $\mathrm{M}_{23} \mathrm{C}_{6}$ type. Austenite is in this group of steels stable even at temperatures well below freezing. Mechanical properties in the solvating annealing, where part of the solution passes into the carbide, depending on the content carbon. Machining austenitic steels is more difficult compared with the low and medium alloy steels.

High strength, low thermal conductivity, high ductility and a tendency to high firming austenitic stainless steels are the main factors that make their machinability difficult. Most 
difficult place to drill deep holes with small diameter, shown Fig.2. Any method of cutting process leaves the surface of certain characteristics and form of a specific surface condition. On the surface of the cut and formed macroprofil and microprofil of surfaces. Force effects a working tool for cutting a thin surface layer beneath the surface of the deformed section. As a result of deformation heating and heat, which always accompanies the process of cutting, are the tensions in this layer and change its physical and mechanical properties.

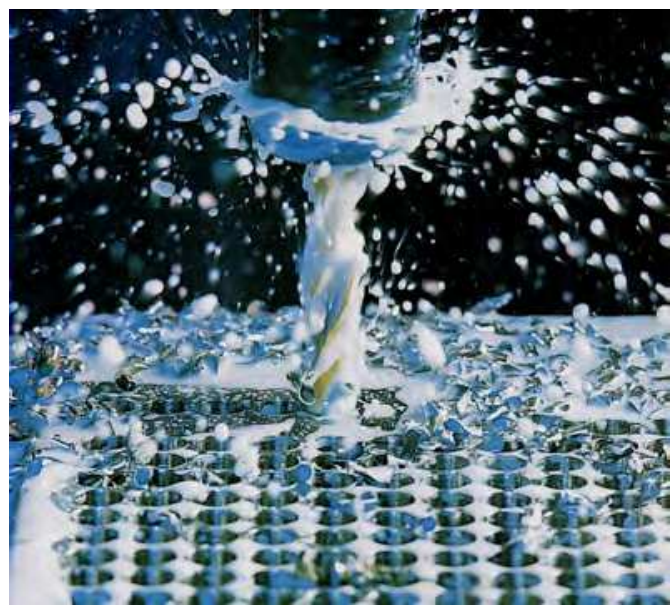

Fig. 2. Drilling process

Problem of machining austenitic steels-austenitic stainless steels are characterized by high toughness, low thermal conductivity and a high degree of hardening of machined surface after machining. In terms the machinability of stainless steel is of great importance especially bonding surface finish. Low thermal conductivity causes adverse creation and shaping of particles in the editing plane, and therefore the material of cutting tools should be applied to sintered carbides. Austenitic steels are more prone to plastic deformation due to the large number of slip systems. Hardening of the machined surface (evaluated by measuring hardness) is the result of transformation of metastable austenite. For working metal, should be seen as a process of plastic deformation. Plastic deformation in relation to the cut surface of an object can take different forms and plastic (hardening), elastic-plastic or elastic. For a group very hard materials, this form of plastic deformation only. On the surface of the section, is of key importance, the thickness of plastically deformed material surface. The various levels of plastically deformed material thickness is a form of distortion varies. Aim of this paper is to present research findings determine the size of the zone of plastic deformation near the surface of the holes drilled by methods of light and electron microscopy and characterized by measuring the intensity of hardening the microhardness values of plastically deformed zone. The paper presents results of deformation of material under the layer surface finish when drilling austenitic stainless steel 1.4303.

According to different authors, very hard materials have ductility that is fifty percent greater than convetional materials, but handle heating more poorly. The specific electrical resistance depends on the chemical composition, not on the structure of the material. For very hard materials it is also characteristic that they have a low thermal conductivity, which 
is mostly a function of the chemical composition. It is important to stress that, as to their mechanical, physical and chemical characteristics, each very hard materials should be studied independently. Working is the result of a mutual interaction of the cutting tool and the workpiece that is accompanied by a number of phenomena that produce the synergic effect. Chip production is described through the plasticity theory. The field of slip lines intervenes with the area of the plastic deformation, the machined surface and the chip. Slip lines represent a durable, highly intense deformation. During the interaction of the cutting elements and the workpiece and due to heat, wearing takes place in the cutting area, because friction depends on the interaction of pure metal surfaces between the frontal surface of the cutting part of the tool and the chip, as it is stated. Wearing is a synergic effect of factors that cause the change of weight, volume or the change of dimensions on the cutting part of the tool. The area of the slip contact has an important role during cutting. The creation of flow zone on the frontal and back surface of the tool called the scab, is one of phenomena resulting from the interaction of the workpiece and the cutting edge of the tool. The order of phases of the scab as a periodic phenomenon that mostly negatively influences the process of cutting. Figure 3 and Figure 4 each photograph includes the information of the thermo-plastic deformation. The paper described verification of CAD systems applied by analysis of drilling tools. Analysis of tool life is very important for proces effectivity.

There is a tendency in the field of machined materials towards stainless steels with higher strength and higher corrosion resistance. Duplex stainless steels are often applied (Schintlmeister \& Wallgram). High-efficiency machining and the machinability of highstrength stainless steels are considered to be the most important future trends affecting machining operations. Duplex stainless steels have a lower nickel content than austenitic stainless steels, and an austenite plus ferrite structure. Increased strength with enhanced properties for service in a corrosive environment provides difficulties from a machinability point of view. The characteristics of stainless steels raised from the austenitic structure are high toughness, low thermal conductivity and high workhardening co-efficient (Peckner \& Bernstein). From a machinability point of view the most important characteristic is the workhardening. Because of the low thermal conductivity, the chips are formed on the basis of catastrophic failure in narrow shear surfaces (Dolinšek). When carbide tools are used these characteristics cause the formation of BUE and low values of tool life. Cutting forces are also increased and the unfavourable formation of tough chips appears (Dolinšek). Tool materials, such as CVD-coated (Chemical Vapour Deposition) with hard $\mathrm{Al}_{2} \mathrm{O}_{3}$ coatings, are often preferred (Belejchak). The need for a hard tool surface coating is especially required when HIPed stainless steels containing hard inclusions are to be machined. Near-equiatomic nickel-titanium alloys (NiTi) have many attractive properties for engineering applications, such as pseudo-elasticity and good cavitation resistivity, in addition to their more wellknown shape memory properties (Li \& Sun, Starosvetsky \& Gotman). In drilling stainless steel with a pseudo-elastic coating material, machinability difficulties are involved with the pseudo-elastic properties of the coating material. Nevertheless, both technical and commercial limitations arise when NiTi is considered as a material for large engineering components. Consequently, interest in NiTi-coating technologies, for example for stainless steels, is on the rise. The cutting process of NiTi-based shape memory alloys is influenced by their high ductility and high degree of workhardening, and the unconventional strain-stress behaviour (Weinert \& Petzoldt). The investigation of machining austenitic stainless steels in different cutting processes has been initiated by industry, where the need for effective tools 
and demands for reliable data on cutting parameters extends far beyond the experiences or recommendations given by tool producers (Dolinšek). The machinability studies are often carried out by $\mathrm{v}_{c} \mathrm{~T}$-tests in turning, milling and drilling operations. Tool wear is studied by using optical microscopy to define the amount of flank and crater wear. The interaction between tool and chip can be effectively studied using SEM. There are several tendencies affecting the technology and methods used in the metalworking industry. Highly efficient machining strategies are used, and HEM (High Efficiency Machining) is used as a machining method. In HEM machine tools, modern tools are used with sufficient cutting parameters. HEM focuses on optimising cutting efficiency to maximise material removal rate. Compared to HSM (High Speed Milling), lower spindle speeds and increased chip thicknesses are used. The modern tools and tool materials available for this research were specifically designed cutting tools for HEM machine tools. The machine tool reliability and productivity is controlled by optimising machining parameter selection and acceptable and adequate sufficient parameters are used. Also, nowadays modern machine tools are very complex mechatronical systems and their capability and efficiency are mainly determined by their kinematics, structural dynamics, computer numerical control system and the machining process (Altintas et al., and Weck et al.).

For materials of the cutting tools are allocated to three variables, which can determine the choice of material, cutting tool in a machining operation:

- wear resistance,

- toughness, respectively. resistance to fracture and deformation,

- wear resistance at elevated temperature.

\section{Examples results from experiments}

\subsection{Example 1}

The material were selected for the purposes of the experiment $\mathrm{X} 4 \mathrm{Cr} 19 \mathrm{Ni}$ s stainless steel, which were then compared to $\mathrm{X} 03 \mathrm{Cr} 16 \mathrm{Ni} 8$ steel. The chemical composition of machined materials is reported in Table 2.

\begin{tabular}{|l|l|l|l|l|l|l|l|l|l|l|}
\hline Element & $\mathrm{C}$ & $\mathrm{Cr}$ & $\mathrm{Ni}$ & $\mathrm{Mn}$ & $\mathrm{Ti}$ & $\mathrm{Mo}$ & $\mathrm{Si}$ & $\mathrm{N}$ & $\mathrm{P}$ & $\mathrm{S}$ \\
\hline X03Cr16Ni8 & 0.3 & 16.0 & 7.5 & 1.8 & - & - & 0.36 & - & 0.04 & 0.03 \\
\hline X4Cr19Ni9 & 0.04 & 19.0 & 9.0 & 1.2 & 0.4 & 0.09 & 0.30 & 0.04 & 0.03 & 0.03 \\
\hline
\end{tabular}

Table 2. Chemical composition of stainless steels in [wt.\%]

X03Cr16Ni8 steel microstructure contains larger quantities of complex carbides.; these are generated along grain edges when compared to $\mathrm{X} 4 \mathrm{Cr} 19 \mathrm{Ni} 9$ steel. For the purposes of the experiments, the applied technical system was: Machine: Chiron FZ12 CNC. Tool: Screw drill with diameter $d=7.0 \mathrm{~mm}$ - new cutting area structure in sintered carbide. Tool fixture: high-precision hydraulic clamping head. Workpiece: the following materials were employed for the purposes of experimental measurements: $\mathrm{X} 03 \mathrm{Cr} 16 \mathrm{Ni} 8$ steel, $\mathrm{X} 4 \mathrm{Cr} 19 \mathrm{Ni} 9$ steel with low carbon content. Samples with the following dimensions were used for the purposes of experimental measurements: $b \times h \times \ell(40 \times 40 \times 200) \mathrm{mm}$. Cutting conditions: cutting speed in interval $v_{c}=40-60 \mathrm{~m}$ per min, feed in interval $f=0.01-0.08 \mathrm{~mm}$ per rev. Machining method: 
Dry Machining. With regard to cutting tool life, the following criterion was applied: $V B_{k}=0.2$ $\mathrm{mm}$. Measurement was carried out by means of an optical microscope without extracting the cutting tool from the clamping fixture. The cutting tools and fragments were analyzed using an electron microscope (SEM).

The result of cutting tool life assessment is $T-v_{c}$ dependence. Analysis of $T-v_{c}$ dependence used a tool with a new cutting area; when drilling $\mathrm{X} 03 \mathrm{Cr} 16 \mathrm{Ni} 8$ steel at $40 \mathrm{~m}$ per min cutting speed, the following drilling length was achieved: $4.5 \mathrm{~m}$ (at feed $f=0.065 \mathrm{~mm}$ per rev.). Due to the increased cutting speed of $60 \mathrm{~m}$ per min, drilling length was reduced to $0.9 \mathrm{~m}$. Tool life was reduced from 16 minutes to 4.5 minutes. When drilling $X 4 \mathrm{Cr} 19 \mathrm{Ni} 9$ steel at $40 \mathrm{~m}$ per min cutting speed, the following drilling length was achieved: $4.0 \mathrm{~m}$ (at feed $f=0.065 \mathrm{~mm}$ per rev.). Due to the increased cutting speed of $60 \mathrm{~m}$ per min, drilling length was reduced to 1.0 $\mathrm{m}$. Tool life was reduced from 9 minutes to 3.0 minutes. When comparing the execution of holes for cutting tools into $\mathrm{X} 03 \mathrm{Cr} 16 \mathrm{Ni} 8$ steel, we observed that tool life was increased by 36 $\%$ compared to $\mathrm{X} 4 \mathrm{Cr} 19 \mathrm{Ni} 9$ steel. The higher percentage of carbon does influence the increase of carbide formation, especially along grain edges; this fact has an impact on cutting tool lifes. By decreasing carbon content we eliminate carbide formation and therefore we increase cutting tool life.

The tendency to generate built-up edges was more significant in the case of $\mathrm{X} 4 \mathrm{Cr} 19 \mathrm{Ni}$ steel than in the case of $\mathrm{X} 03 \mathrm{Cr} 16 \mathrm{Ni} 8$ steel. One example of BUE formation for $\mathrm{X} 4 \mathrm{Cr} 19 \mathrm{Ni} 9$ steel during drilling followed these cutting conditions: cutting speed $v_{c}=45 \mathrm{~m}$ per $\mathrm{min}$, feed $f=0.065 \mathrm{~mm}$ per rev. A cutting speed increase has an impact on BUE formation over the front area. By comparing the steels it was ascertained that in the case of $\mathrm{X} 03 \mathrm{Cr} 16 \mathrm{Ni} 8$ steel the corner was not worn (unlike $\mathrm{X} 4 \mathrm{Cr} 19 \mathrm{Ni} 9$ steel). BUE formation over the face area and cutting part shape (geometry) influence the chipping on the cutting edge. An electron microscope was used for wear analysis for sintered carbide cutting tools (SEM - Scanning Electron Microscopy). Qualitative and quantitative workpiece modifications do occur in the cutting zone. With regard to circumstances in the cutting zone, it is important to be aware of the input features of interacting objects (tool and workpiece) as well as of conditions influencing such interaction from the point of view of machining equipment. Output elements generated from the cutting: a workpiece with a machined surface, and tool with possible cutting area damage. For the purposes of analysis of the creation and shaping of chips, the samples were examined using an SEM according to the following cutting conditions: cutting speed $v_{c}=40$ and $60 \mathrm{~m}$ per min. $\mathrm{X} 03 \mathrm{Cr} 16 \mathrm{Ni} 8$ steel chips; $\mathrm{X} 4 \mathrm{Cr} 19 \mathrm{Ni} 9$ steel chips are illustrated; These figures illustrate the chip surfaces from their concave and convex sides. Cutting tool wear increased when cutting speed rose from 40 to $60 \mathrm{~m}$ per min. At this cutting speed interval it was possible to observe a tendency to make larger BUE in the case of X03Cr16Ni8 steel compared to $\mathrm{X} 4 \mathrm{Cr} 19 \mathrm{Ni} 9$ steel. Here we can observe traces/grooves as a result of the interaction between the chip and the front area of the tool. The concave side of the chip (dished chip) reported in Fig.3 shows a modification of the thickness of the elements/flakes (lamellae) when cutting speed increased. The higher tendency of BUE formation with X03Cr16Ni8 steel can be compared against the fragment surface (convex shape). Worse (reduced) machinability (resulting from the comparison of $\mathrm{X} 03 \mathrm{Cr} 16 \mathrm{Ni} 8$ and $\mathrm{X} 4 \mathrm{Cr} 19 \mathrm{Ni9}$ ) could be caused by the irregular tooth-like endings on the convex (protuberant) sides of the chip. When comparing the chips with $\mathrm{X} 03 \mathrm{Cr} 16 \mathrm{Ni} 8$ and $\mathrm{X} 4 \mathrm{Cr} 19 \mathrm{Ni}$, it is possible to observe grooves (depressions) and protruding material. Chip shaping is influenced by structurally 
unstable effects. Tool wear occurred continuously for $\mathrm{X} 03 \mathrm{Cr} 16 \mathrm{Ni} 8$ steel with the use of a cutting tool in dry machining. In this respect, at increasing cutting speeds tool plastic deformation takes place with gradual laminar flaking of the surface on the cutting tool (Fig. 3a) and with destruction of the coat (frittering) over the front area (Fig.3b); tool wear is influenced by the formation of built-up edges and by coat flaking.

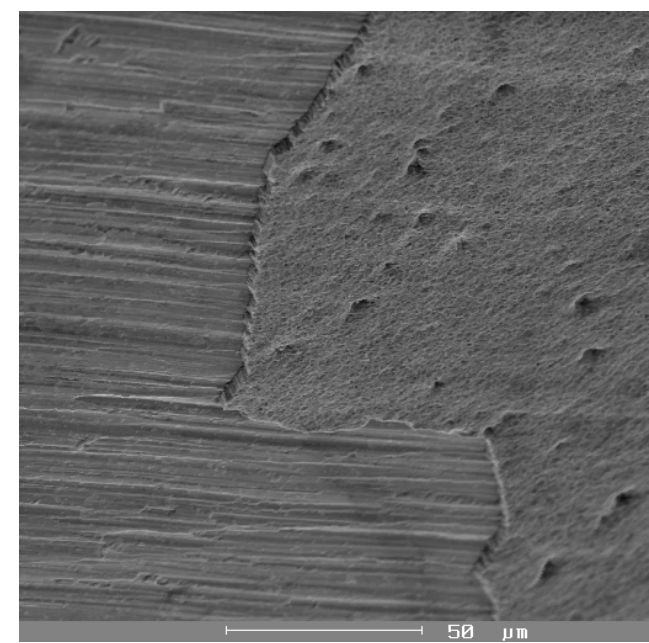

(a)

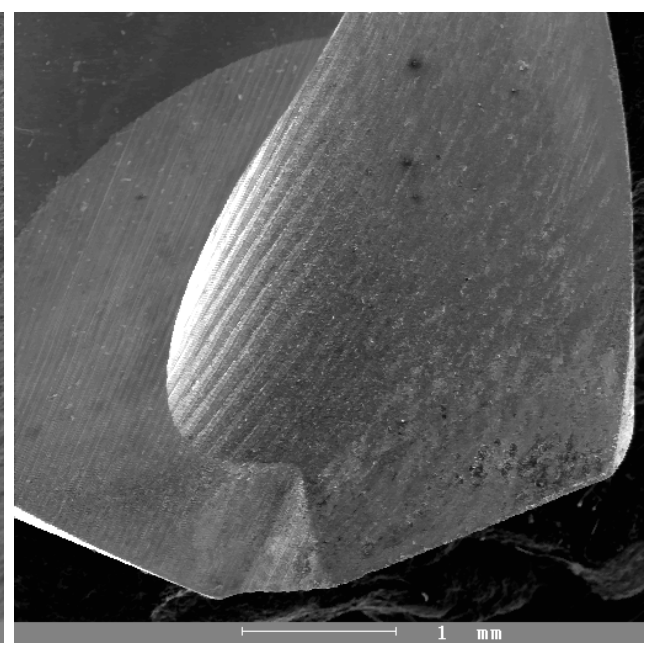

(b)

Fig. 3. Helical drill - characteristical wear in cutting part. (a) Coat damage on dorsal area gradual coat laminar flaking on cutting tool. (b) Coat damage - destruction (frittering) on front area

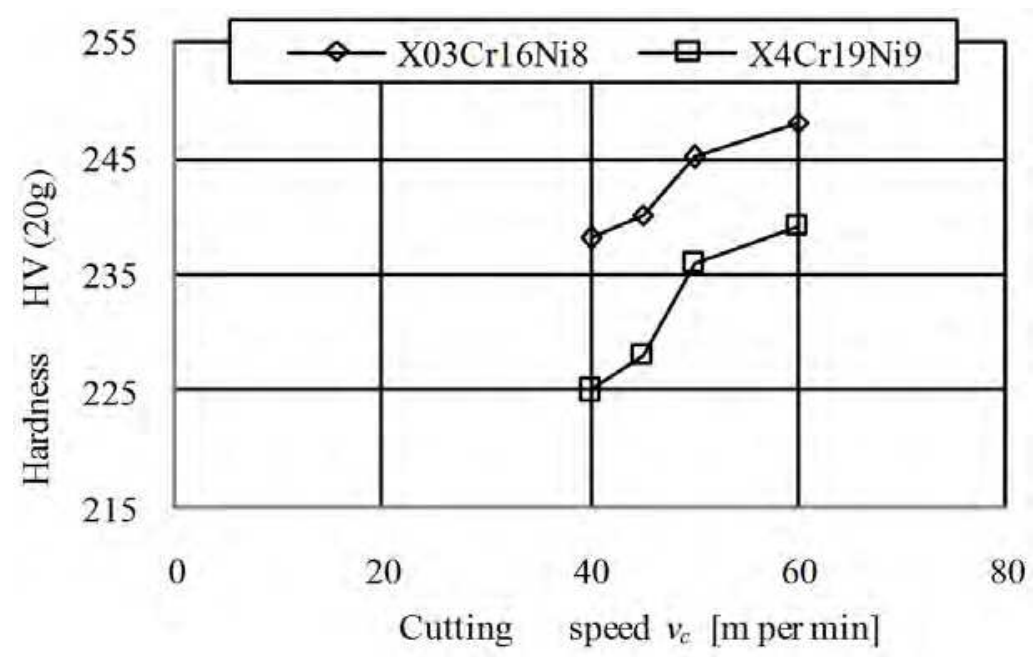

Fig. 4. Relation between machined workpiece micro-hardness and cutting speed when drilling holes into $\mathrm{X} 03 \mathrm{Cr} 16 \mathrm{Ni} 8$ and $\mathrm{X} 4 \mathrm{Cr} 19 \mathrm{Ni} 9$ steels, with feed $0.065 \mathrm{~mm}$ per rev. 
Stainless steels are influenced by charging due to intensive mechanical reinforcement during machining. The examination of reinforced surfaces can be carried out by measuring the micro-hardness of the bottom part of the fragment; indeed, the bottom part of the fragment can be considered as the most deformed fragment zone. The results of micro-hardness examination are reported in Fig. 4, these results are as follows: $\mathrm{X} 03 \mathrm{Cr} 16 \mathrm{Ni}$ s steel: fragments are strongly deformed compared to $\mathrm{X} 4 \mathrm{Cr} 19 \mathrm{Ni} 9$ steel. Austenite fragment, bottom part, $v_{c}=60$ $\mathrm{m}$ per min, $310 \mathrm{HV}(20 \mathrm{~g})$, if the bottom part of the fragment is measured: austenite $240 \mathrm{HV}$ $(20 \mathrm{~g})$. 2. X4Cr19Ni9 steel: $v_{c}=45 \mathrm{~m}$ per min, austenite microhardness $230 \mathrm{HV}(20 \mathrm{~g})$, if the bottom part of the fragment is measured: austenite $234 \mathrm{HV}(20 \mathrm{~g})$. The results presented in this article can be summarized as stated in the following main conclusions for the sake of comparison:

1. Machinability of $\mathrm{X} 03 \mathrm{Cr} 16 \mathrm{Ni} 8$ steel and $\mathrm{X} 4 \mathrm{Cr} 19 \mathrm{Ni} 9$ steel is influenced by the formation of BUE. X03Cr16Ni8 steel tends to form more BUE than X4Cr19Ni9 steel

2. Tool life (for the applied cutting tool) is between $4.5 \mathrm{~min}$. and $12 \mathrm{~min}$., when drilling X4Cr19Ni9 steel.

3. BUE formation is caused by adhesive wear; in terms of cohesion, this fact indicates that the above mentioned mechanism is likely to be the predominant mechanism in the damaging process of sintered carbide tools when drilling into $\mathrm{X} 4 \mathrm{Cr} 19 \mathrm{Ni} 9$ steel.

\subsection{Example 2}

During the drilling simulation, the cutting edges of the drill bit are shearing the workpiece material at high speeds which separate the material from the workpiece by chip formation. The material separation criterion for machining has been a topic of interest in the development of the theory of finite element modeling of machining. Initially, a parting line model was assumed to simplify the simulation process. This model assumed a small crack existed in the material and the chip was separated from the workpiece in a predetermined "unzipping" fashion. Eventually, the maximum plastic strain model was proposed and this criterion has been adopted by most FEM models. This maximum plastic strain model assumes that material separation occurs when an element reaches a critical plastic strain for the material model of the workpiece. The element is then split into two elements and a chip is formed. One can argue whether drilling actually produces smooth separation. Regardless, the maximum plastic strain criterion has been implemented and this has been the most accepted method of failure criteria to model burr formation in drilling. Historically, the two standard FEM meshes are Eulerian and Lagrangian. There are also combinations such as the Arbitrary Lagrangian Eulerian (ALE) and the Coupled Eulerian Lagrangian (CEL) meshes. Although the Lagrangian mesh is not as comprehensive as the Eulerian mesh, it has much better simulation cycle times as a result. Lagrangian mesh in simulating drilling processes is the ability to know the entire time history of the key variables at every point during the simulation. That means, if a simulation crashes for any reason, a new simulation can start where the crashed simulation stopped. This is particularly useful because nearly every simulation has some sort of problem during the run. This is possible because the Lagrangian mesh is reformulated at nearly every time step, in order to manage the deformation of the material. Several different types of machining operations can be accomplished with 
Proengineer including drilling, turning, and milling. If a tool geometry can be modeled, the machining operation can be simulated. One of the most difficult problems faced with modeling drilling operations is obtaining an accurate model of a drill bit. More authors both present how this can be done and the latter developed a program to do this quickly and easily. Fig. 5,Fig. 6, Fig.7., Fig. 8., Fig.9., Fig. 10. each photograph includes the information of the thermo-plastic deformation. The paper described verification of CAD systems applied by analysis of drilling tools. Analysis of tool life is very important for proces effectivity.

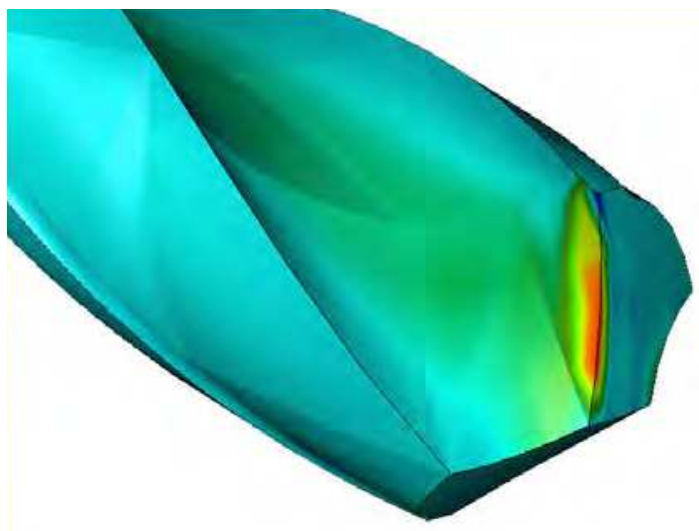

"windowl" - dipl stat F 572 - dipl stat F 572

(a)

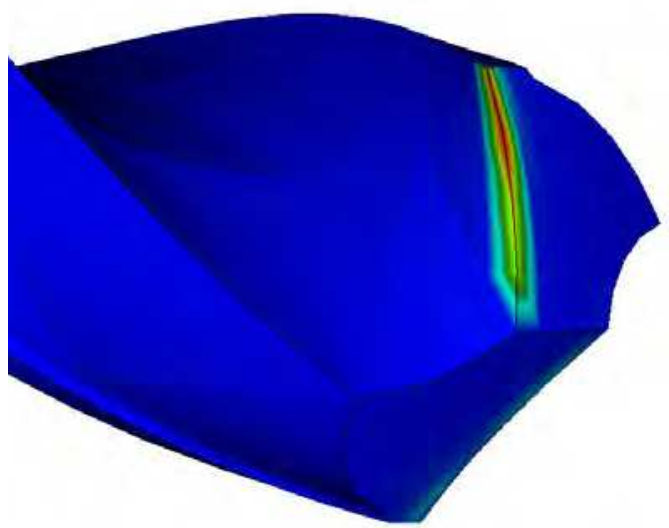

"windowl" - diol stat F 572 - diot stat F 572

(b)

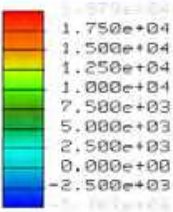

$9.677 \varepsilon+04$ $9.637 e+04$
$867 e+04$ ?. $4967 e+104$ $5.425 e+04$ $5.354 e+04$ 4. $2830+04$

$3.2320+04$

2. $142 \mathrm{et}+04$

1. $0710+04$

Fig. 5. Modeling of screw drill. (a) Tool wear- stress on the cutting edge. (b) Tool wear plastic deformation on the cutting edge 


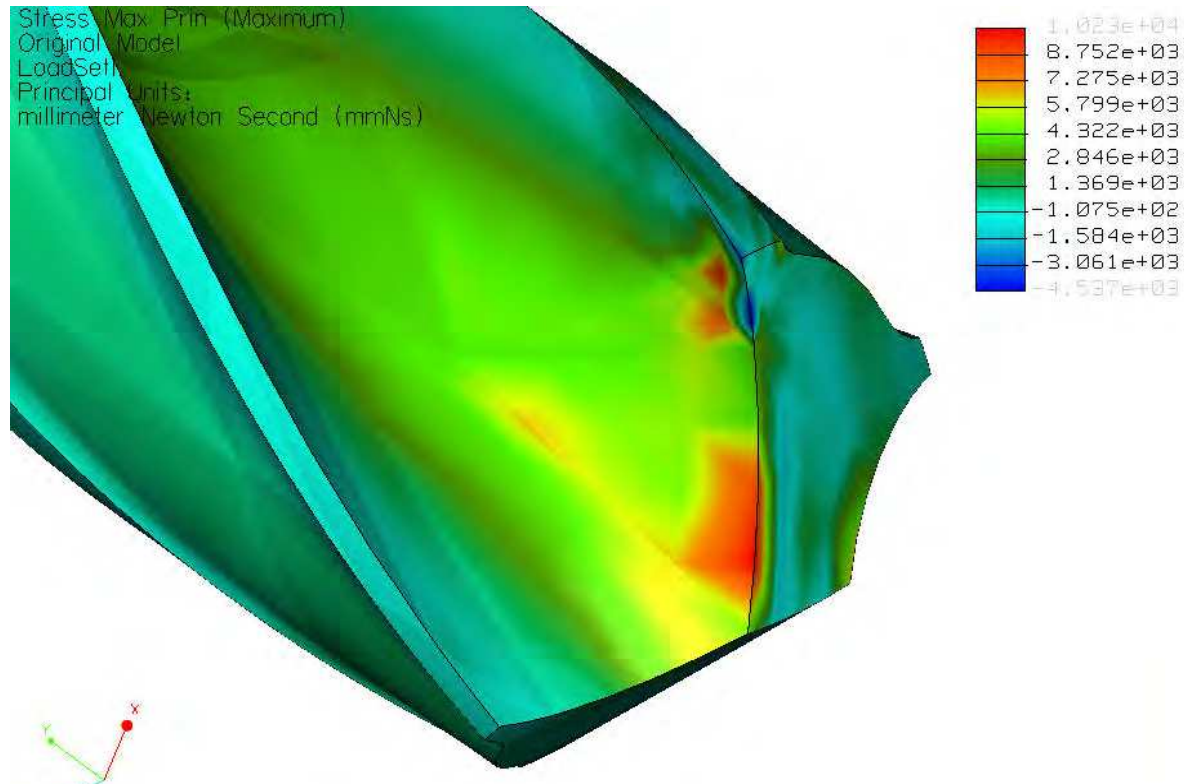

(a)

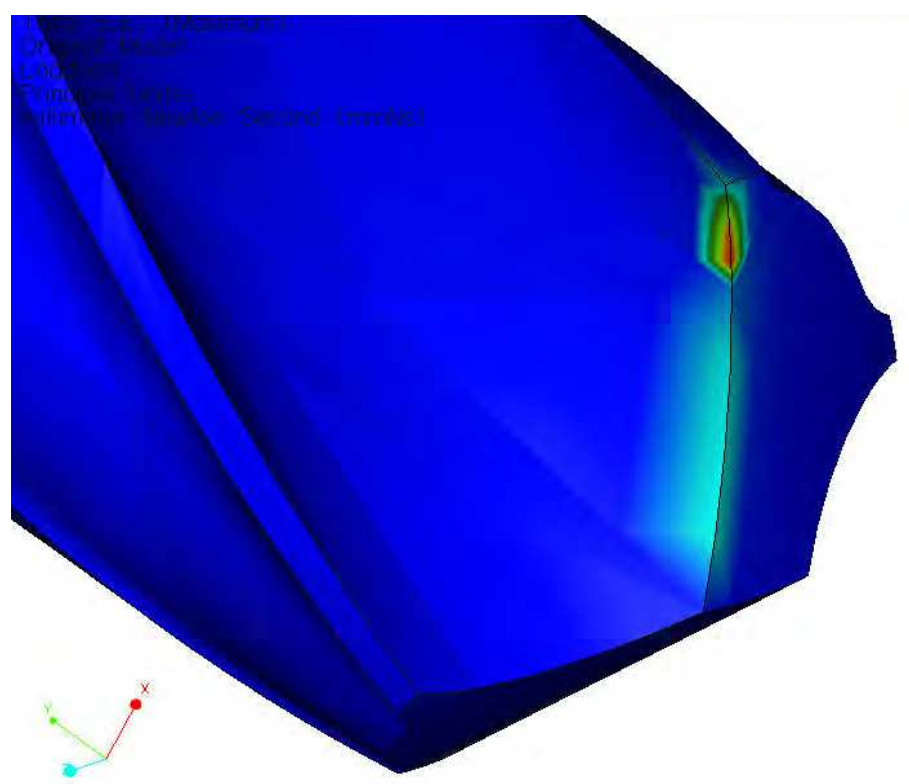

9. $900+04$

8. $00 \square e+04$

7. $000 \mathrm{e}+04$

6. $\square \Delta \square e+\square 4$

5. $000 e+04$

4. $\square \square \square e+\square 4$

3. $000 \mathrm{e}+04$

2. $000 \mathrm{e}+04$

1. $\square \square \square e+\square 4$

(b)

Fig. 6. Modeling of screw drill with two margins. (a) Tool wear- stress on the cutting edge. (b) Tool wear - plastic deformation on the cutting edge 


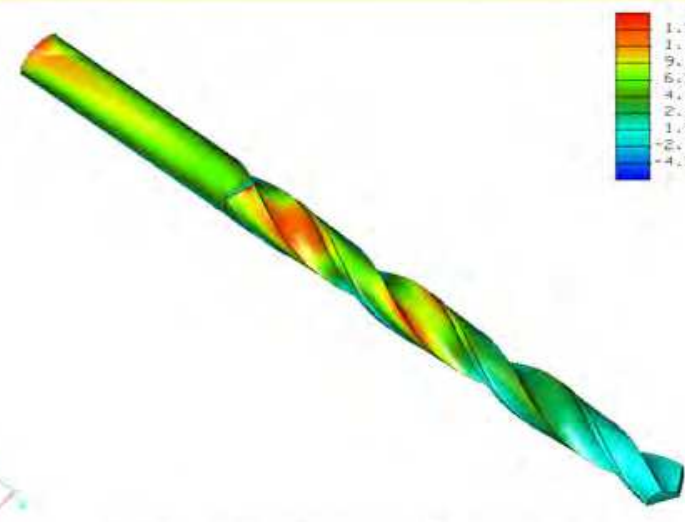

Fig. 7. Modeling of screw drill - Tool wear- stress on the cutting edge

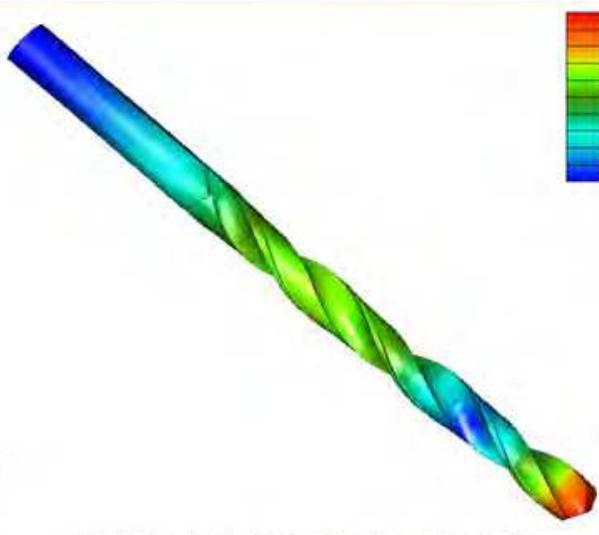

"wirdowl" - dol modol f 572 - dial madal F. 572

Fig. 8. Modeling of screw drill - Load on the cutting part

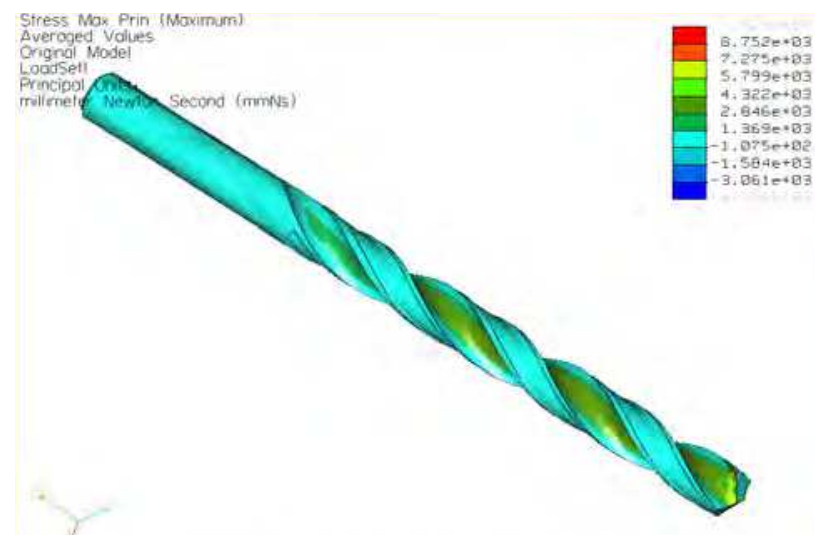

Fig. 9. Modeling of screw drill with two margins - stress on the cutting part 


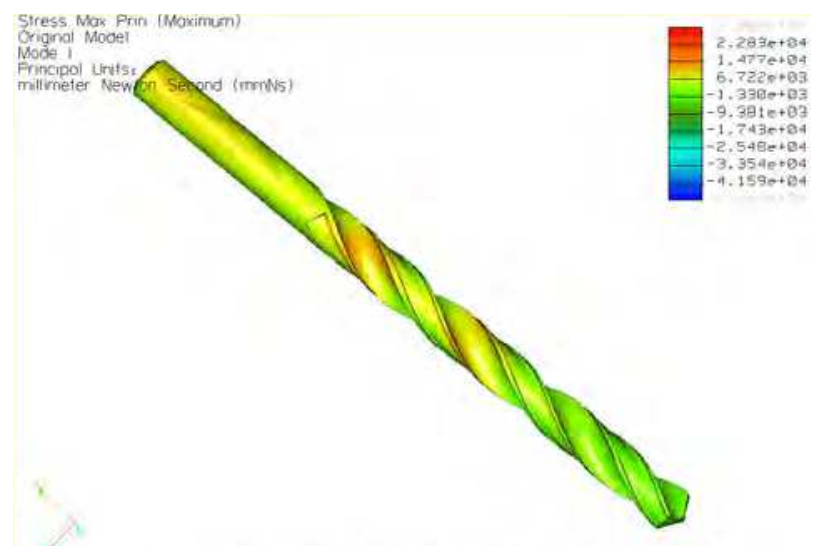

Fig. 10. Modeling of screw drill with two margins - Load on the cutting part

The cutting edge of an insert in a finishing operation is worn out when it can no longer generate a certain surface texture. Not a lot of wear is needed along a very small part of the insert nose for the edge of an insert to need changing. In a roughing operation wear develops along a lot longer part of the edge and considerably more wear can be tolerated as there are no surface texture limitations and accuracy is not close. The tool-life may be limited when the edge looses its chip control ability or when the wear pattern has developed to a stage when the risk for edge breakdown is imminent.

\subsection{Example 3}

For the experiments was applied technological system machine-tool-workpiece-fixture: CNC Chiron FZ12, helical drill with a diameter $d=7.0 \mathrm{~mm}$, the new design of the cutting edge with uncoated cemented carbide. Fixture for the cutting tool: high precision hydraulic clamping head, the workpiece fixture: mechanical vise. Workpiece: stainless steel-austenitic X4Cr17Ni8 steel. The materials to be machined were type of a new austenitic stainless steels with chemical composition listed in Tab.3. Experiments were used for sample size $h x b x l$

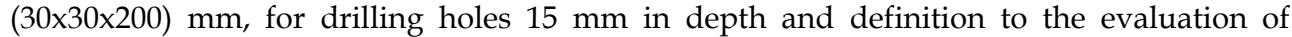
internal machined surface. Cutting conditions: cutting speed of $v_{c}=$ interval of $20-60 \mathrm{~m} / \mathrm{min}$, feed $f=$ interval from 0.01 to $0.08 \mathrm{~mm}$ per revolution, depth of cut $a_{p}=3.5 \mathrm{~mm}$. Method of machining and dry machining. Workpieces of $\mathrm{X} 4 \mathrm{Cr} 17 \mathrm{Ni} 8$ steel, obtained by drilling, were analyzed for electron microscopy. To deformed the steel-hardening layer, was rated a hard layer width from the cut surface, a hard layer microhardness, and surface finish has been rated $R a$ surface roughness and surface morphology.

\begin{tabular}{cccccccc}
\hline $\mathrm{C}$ & $\mathrm{Cr}$ & $\mathrm{Ni}$ & $\mathrm{Mn}$ & $\mathrm{Si}$ & $\mathrm{P}$ & $\mathrm{Ti}$ & $\mathrm{S}$ \\
\hline 0.04 & 17.2 & 8.2 & 1.6 & 0.6 & 0.04 & 0.06 & 0.03 \\
\hline
\end{tabular}

Table 3. Chemical composition of stainless steels in wt [\%]

The parameters of the process of drilling holes and dimensional characteristics of the drill are: T1(feed is $0.01 \mathrm{~mm}$, cutting speed is $20 \mathrm{~m} / \mathrm{min}$., $d=7 \mathrm{~mm}$, angle $2 \mathrm{~K}_{\mathrm{r}}=135^{\circ}$ ), T2 (feed is $0.065 \mathrm{~mm}$, cutting speed is $35 \mathrm{~m} / \mathrm{min}$., $d=7 \mathrm{~mm}$, angle $2 \mathrm{~K}_{\mathrm{r}}=135^{\circ}$ ), T3 (feed is $0.08 \mathrm{~mm}$, cutting 
speed is $40 \mathrm{~m} / \mathrm{min} ., d=7 \mathrm{~mm}$, angle $2 \mathrm{~K}_{\mathrm{r}}=135^{\circ}$ ). Workpieces for metallographic analysis were collected spark so that the plane metallographic sections axis hole. Subsequently, the workpieces were prepared and ready in dentacryle conventional metallographic procedures. For purposes of analysis has been used light microscopy experimental technique: an inverted metallographic microscope for observation in polarized light and differential interference contrast using (DIC). To verify the value of the depth of plastically deformed zones around the drilled holes (determined by light microscopy) technique was used for scanning electron microscopy - with a JEOL JSM 7000F autoemission nozzle. Microhardness plastically deformed zone was set at a distance of $60 \mu \mathrm{m}$ for austenitic steel X4Cr17Ni8 steel. Methods of light and scanning electron microscopy was specified range plastically deformed zones in drill holes under the surface of the material X4Cr17Ni8 steel. Local hardening plastically defor-med zone around the drill holes was characterized by measuring the microhardness LM 700 AT micro-hardness with a load of $0.2452 \mathrm{~N}$. For more information about local hardening deformed zone in the E position drill holes were obtained by measuring the indentation hardness apparatus Nanoindentation Hardness Tester - TTX NHT2 CSM method, where the grow monotonous load is superimposed small sinusoidal load. Measurement parameters Berkovich indenter types were: feed rate indenter 3000 $\mathrm{nm} / \mathrm{min}$, a maximum load of $100 \mathrm{mN}$, loading and unloading speed $200 \mathrm{mN} / \mathrm{min}$, sinus frequency $20 \mathrm{~Hz}$, amplitude sinusoidal load of $5 \mathrm{mN}$, stay to the maximum load of $10 \mathrm{~s}$. Indentation measurements were in the position E hole. Analyses of samples plastically deformed layers under the surface of machined steel $\mathrm{X} 4 \mathrm{Cr} 17 \mathrm{Ni} 8$ steel can confirm these allegations. Autors indicates that for $\mathrm{X} 4 \mathrm{Cr} 17 \mathrm{Ni} 8$ steel, resizing a layer of plastic deformation is related mainly to the material structure and properties of austenitic grain size.

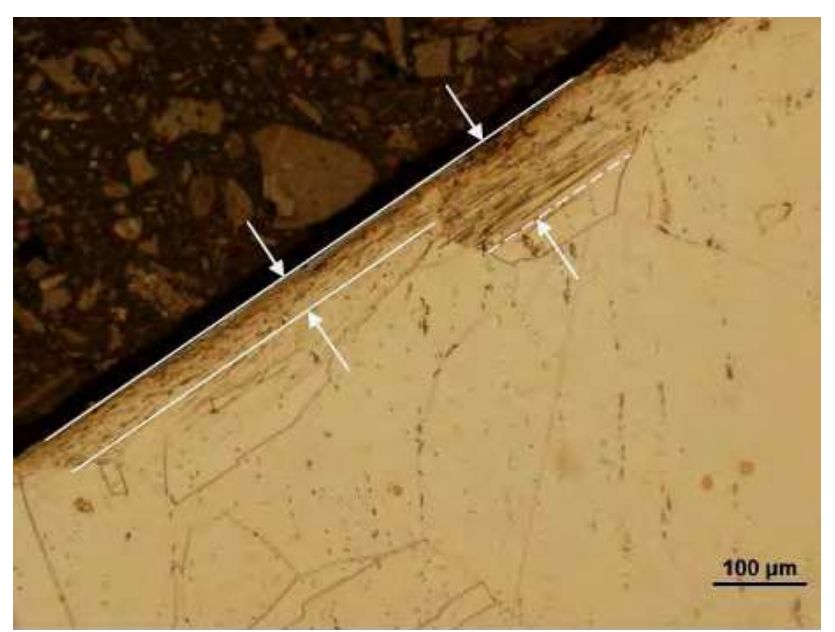

Fig. 11. Plastic deformation of the surface, local plastic deformation in austenitic grainhardening surface, zone of hole $\mathrm{F}$

Hardening uneven layer width from $30 \mu \mathrm{m}$ to $550 \mu \mathrm{m}$, example as shown in Fig.11, generated by the cutting conditions of $50 \mathrm{~m} / \mathrm{min}$ to $60 \mathrm{~m} / \mathrm{min}$ and feeds on larger than 0.06 $\mathrm{mm}$. Plastic deformation of the machined surface has the character in Fig.12. 


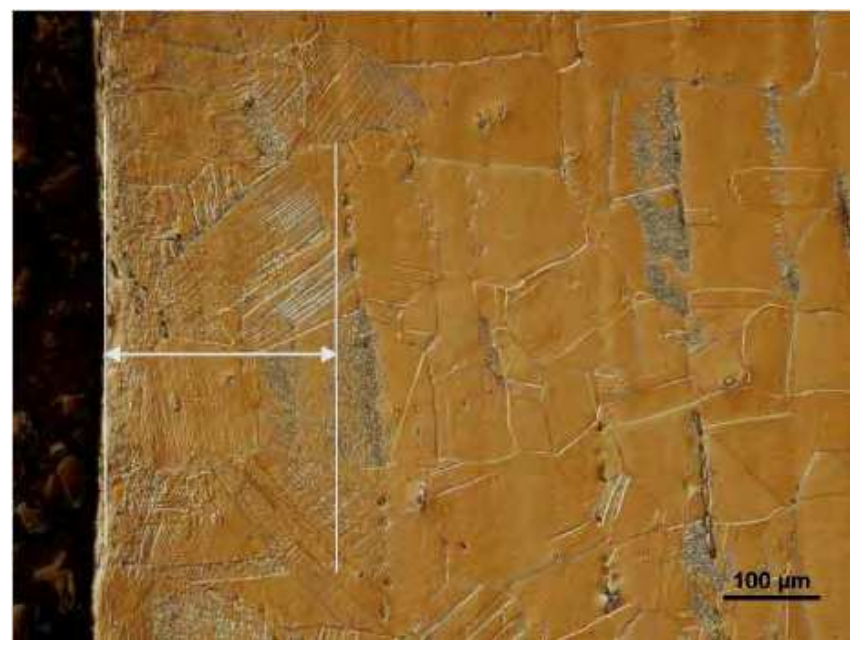

Fig. 12. Plastic deformation of the surface to a depth of $220 \mu \mathrm{m}$, local plastic deformation in the austenitic grain, zone of hole $\mathrm{H}$

To plastic deformation occurs under the surface finish and the local austenite grains. At a cutting speed of $30 \mathrm{~m} / \mathrm{min}$ to $45 \mathrm{~m} / \mathrm{min}$ and feeds from $0.04 \mathrm{~mm}$ to $0.08 \mathrm{~mm}$ width was measured to strengthen the layers from $20 \mu \mathrm{m}$ to $68 \mu \mathrm{m}$, which is plastically deformed smallest layer, as shown Fig.13. Under these conditions, the cutting width was measured to be uniform solidified layer. At the same time claim autor ${ }^{2}$ confirmed that this is true for smaller austenite grains ( $\sim$ to $80 \mu \mathrm{m})$. Hardness HV (20g) in plastically deformed layer after drilling $\mathrm{X} 4 \mathrm{Cr} 17 \mathrm{Ni} 8$ steel Fig.14 shows. For the evaluation of machined surface was measured roughness $R a=0.85 \mu \mathrm{m}$ at a cutting speed of $50 \mathrm{~m} / \mathrm{min}$ and feed is $0.04 \mathrm{~mm}$.

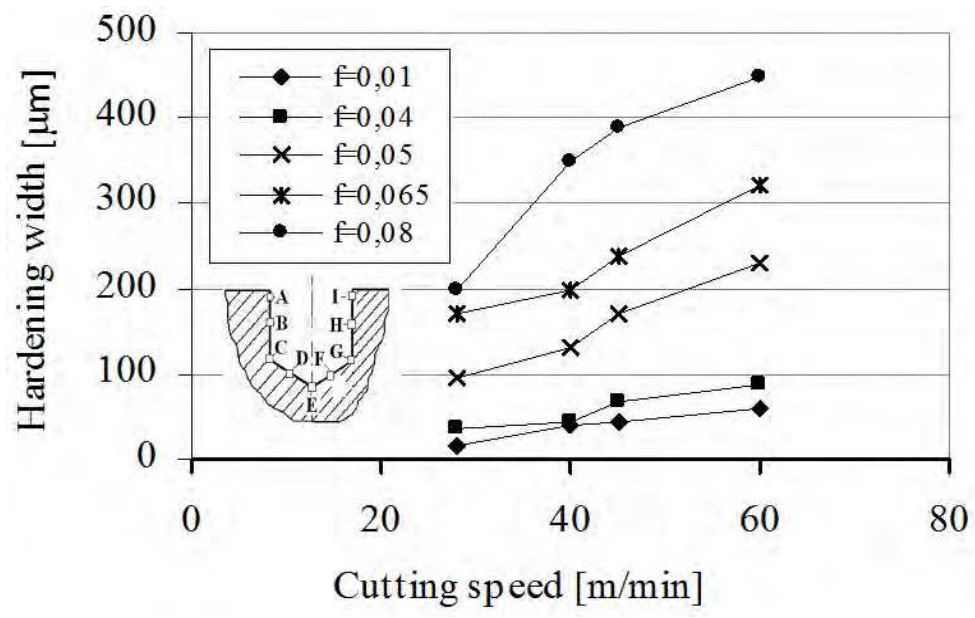

Fig. 13. Dependence of width of the deformed area of cutting speed and different feed, zone of hole $\mathrm{F}$ 


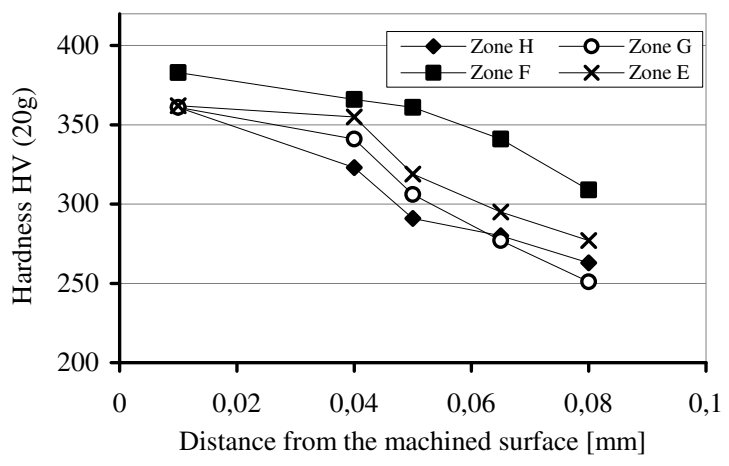

Fig. 14. Dependence of the hardness of the deformed distance from the machined surface

When the measured surface roughness $R a=0.85 \mu \mathrm{m}$ (minimum of surface roughness) width was measured to strengthen the layers from $20 \mu \mathrm{m}$ to $48 \mu \mathrm{m}$. This result was achieved, the plastically deformed layer can be taken further by removing (example: at increasing of holes diameter, or threadings) and by extending tool life by 20 to $30 \%$, and thus eliminate the catastrophic damage of tool. For evaluation of the cutting tools life were applied criterion $\mathrm{VB}_{\mathrm{k}}=0.1 \mathrm{~mm}$. Measurements were made using an optical microscope without removing the cutting tool from the fixture. Cutting tools and the chips were analyzed for electron microscopy (SEM). Plastic deformation initiates the so-called cutting edge wear. chipping, especially for the discontinuous method of machining such as drilling. This phenomenon is called plastic lowering the cutting edge. Light microscopy and SEM was measured amount of plastic strain in the top spot (position E) 18 to $152 \mu \mathrm{m}$. In these areas was measured indentation hardness HIT, depending on the depth of indenter penetration. The measurement matrix was $3 \times 3$ indentation impress whose mutual distance was $18 \mu \mathrm{m}$. The minimum distance from the indenter impresses edge of the sample was $18 \mu \mathrm{m}$. Maximum indentation hardness values were measured in the top spot at the sample $\mathrm{X} 4 \mathrm{Cr} 17 \mathrm{Ni} 8$ steel. In this position he was microscopically measured maximum value of local plastic deformation of $\sim 152 \mu \mathrm{m}$.

\subsection{Example 4}

Study of cutting tool wear with regard to the elimination of occurrence of poor-quality holes when drilling into new austenitic ELC (Extra Low Carbon) stainless steel. The problem of drilling holes with diameter $D=5$ to $8 \mathrm{~mm}$ resides in the fact that 30 to $35 \%$ of these holes do not comply with prescribed requested requirements. The cutting tools (helical drills as monoliths) get damaged and wear out. The result of the damage is very often the unforeseen destruction of the cutting tools; therefore their operational tool life is reduced. On the basis of practical experience and experiments carried out in the past 15 years, we have observed that the operational tool life of helical drills is reduced by 30 to $40 \%$. This article presents the results of experiments focusing on the study of the damage process in helical drills with diameter $d=8.0 \mathrm{~mm}$ when drilling into new austenitic ELC stainless steel. This study also includes an analysis of accompanying phenomena in the cutting zone by measuring some selected parameters. The results of the experiments were compared with $\mathrm{X} 2 \mathrm{Cr} 18 \mathrm{Ni} 8$ steel and then 
verified when drilling holes into specific products. Production technology is the fundamental aspect in terms of requested values for the production of components. The relationship between the quality of a machined component surface and the applied technical machining method can be assessed using the following factors (Abrao, A.M. \& Aspinwall, D.K.):

- Machined surface in the space (e.g. morphology, texture and surface roughness)

- Features of machined surface (e.g. dimension and hardness)

- Impact of the technical machining method over the features of the machined surface and their direct influence on the function of the component (e.g. surface defects, impurities and inclusions)

During the machining process, the following phenomena occur on the machined surface:

- Plastic deformation of the machined surface,

- Structural modification of the machined surface,

- Modification of mechanical features of the machined surface,

- Modification of the integrity of the machined surface,

- Modification of residual tension under the machined surface,

- Modification of chemical features of the machined surface.

Austenitic stainless steels are characterised by high strength, low heat conductivity, and a high degree of hardening of the machined surface after machining (Belluco, L. \& De Chiffre, L.), (Peckner, D. \& Bernstein, I.M.). With regard to the machinability of stainless steels, the hardening of the machined surface is a very significant aspect. Low heat conductivity causes negative formation and shaping of chips in the shear plane (Brinksmeier, E.W. \& Reucher, A. \& Griet-Solter, J.), (Dolinšek, S.); therefore, as far as cutting tool materials are concerned, it is necessary to apply sintered carbides. When machining stainless steels, we often note the occurrence of built-up edge; this phenomenon results in a reduction of tool life (Ceretti, E. \& Giardini, C. \& Filice, A. \& Rizzuti, L. \& Umbrello, S.D.), (Jurko, J. \& Panda, A. \& Gajdoš, M.) Cutting tool wear is the result of the combination of various wear mechanisms: abrasive, adhesive, diffuse, and chemical (oxidation), (Grzesik, W.). Generally speaking, with regard to sintered carbide tools the most dominant types of phenomena are in the following order: abrasive, adhesive, diffuse, and chemical wearing mechanism (Jurko, J.), (Jurko, J. \& Panda, A.). As for tool cutting area materials, three parameters are selected, through which it is possible to define the choice of tool cutting area material with regard to a given machining operation:

- Resistance against wear

- $\quad$ Strength, i.e. resistance against breaking and deformations

- Resistance against wear at increased temperature.

According to (Liew, W. \& Ngoi, B. \& Lu, Y.): “Wear is an undesired modification of the surface or of the dimensions of solid bodies; such modification is caused either by the mutual action of functional surfaces or by mutual action of the functional surface and the environment - generating wear during their mutual relative movement".

Cutting tool wear is the result of a combination of encumbering factors influencing the cutting area of a tool. Wear is then the interaction between the cutting tool, workpiece 
material, and cutting and machining conditions (Nam, P. Suh). In terms of the technical method for drilling, mutual interaction is generated between the cutting area of the tool and the workpiece, according to the following steps (Jurko, J. \& Panda, A. \& Gajdoš, M.):

- First contact occurs when the elements - edges of the surface of the peak of the helical drill - are pushed into workpiece material (chisel cutting interaction edge/workpiece),

- Progressive incision of the chisel cutting edge into the workpiece over a length $\ell_{\mathrm{sw}, 2}$

- Progressive incision of the cutting edges into the workpiece over a length $\ell_{\mathrm{s}}$ (length of the major cutting edge); this data is calculated according to equation 3

$$
\ell_{s} \cong \frac{d}{2 \cdot \sin \kappa_{r}}[\mathrm{~mm}]
$$

where

$\ell_{\mathrm{s}}$ - length of the major cutting edge in [mm],

$d$ - drill diameter in [mm],

$\kappa_{\mathrm{r}}$ - tool cutting edge angle in [ $\left.{ }^{\circ}\right]$,

$\ell_{\mathrm{s}, 1}, \ell_{\mathrm{s}, 2}$ - lengths of cutting edges on a double-wedge helical drill in [mm]

and the following equation 4 is valid:

$$
\ell_{S}, 1=\ell_{S}, 2 \equiv \ell_{S}[\mathrm{~mm}]
$$

provided that the cutting edge of the tool is symmetrically reground.

- The progressive incision of the cutting edges into workpiece material ends at point $\mathrm{H}$ (corner of tool cutting part). The process of cutting edge incision is different in each single point of this cutting edge; this happens because of modifications concerning the kinetic rates for each single cutting edge point. Cutting speed $v_{c}$ changes from point $\mathrm{V}$ (peak of tool cutting part) - where $v_{c}=0 \mathrm{~m}$ per min - up to point $\mathrm{H}$ (corner in the tool cutting part), where maximum cutting speed is defined by this equation 5 :

$$
v_{C, \max }=\frac{\pi \cdot d \cdot n_{C}}{1000}
$$

in $\mathrm{m}$ per min. As a result of such kinetic rates, during incision we observe various forms of damage in the elements of tool cutting area - specifically it happens in the following way for one cutting wedge: at peak $\mathrm{V}$, or at the transversal cutting edge, with continuous progressive incision of the main cutting edge, we observe damage in the major flank area and in the face area; the damage process continues on at point $\mathrm{H}$, proceeding towards the adjacent cutting edge and towards the minor flank areas. In Fig.15. we reported the main elements and sectors on the helical drill in terms of damage (successively we can exactly measure and assess these elements and sectors). The type and course of wear originated on the cutting area of the tool provide important information about the course of machining. 

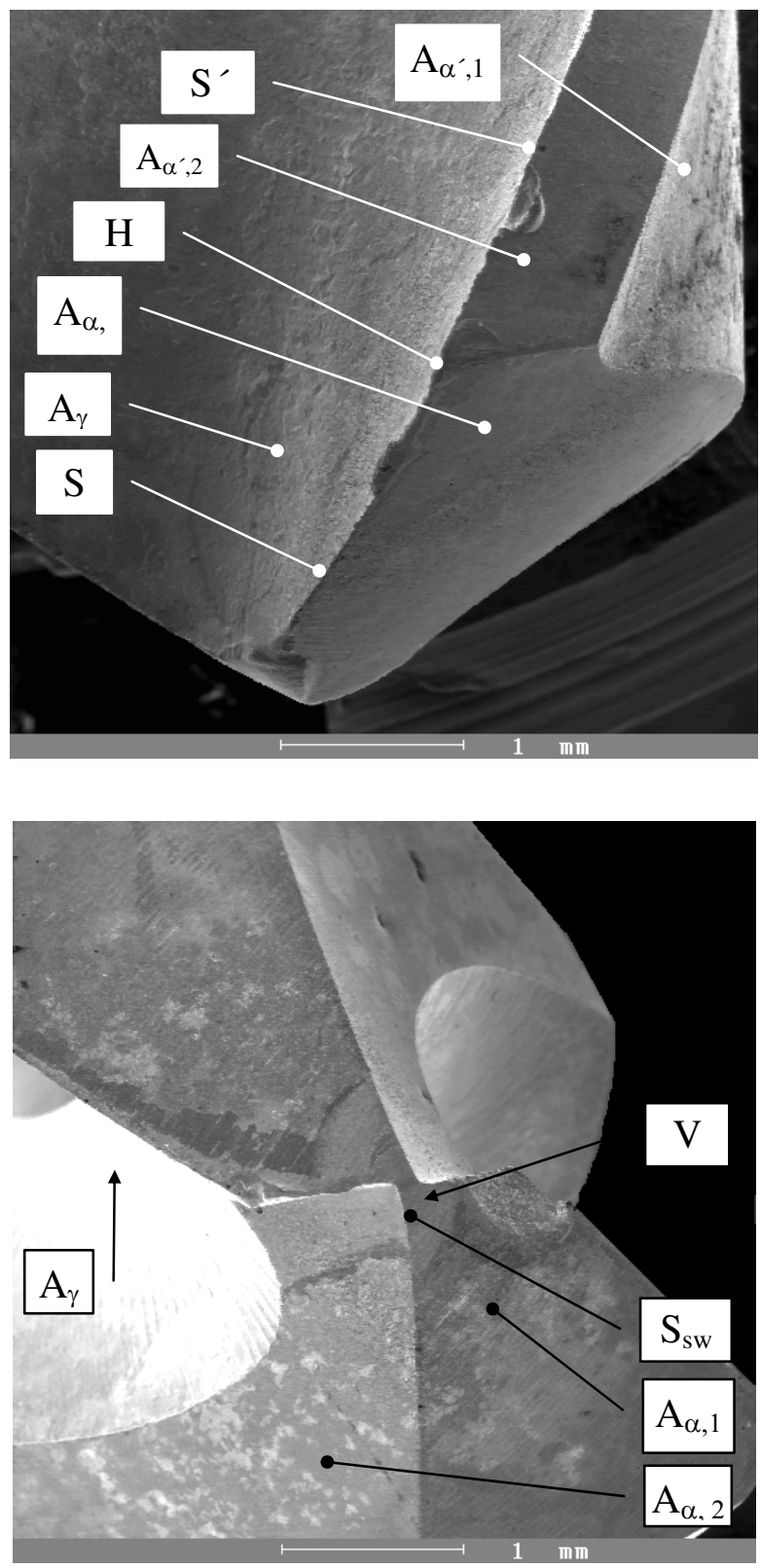

$\mathrm{A}_{\gamma}$ - face area, $\mathrm{A}_{\alpha, 1}$ - major flank area, $\mathrm{A}_{\alpha, 2}$ - major flank area - relieved,

$\mathrm{A}_{\alpha^{\prime}, 1}$ - minor flank area, $\mathrm{A}_{\alpha^{\prime}, 2}$ - minor flank area (margin), H-corner, V-peak,

$\mathrm{S}$ - major cutting edge, $\mathrm{S}^{\prime}$ - minor cutting edge, $\mathrm{S}_{\mathrm{sw}}$ - chisel cutting edge

Fig. 15. Main elements and sectors related to wear on the cutting part of the helical drill 
Studies and research about machinability of materials often focus on assessment results of cutting tool life. Cutting tool wear is a parameter we can examine by means of an optical light microscope. The examination of the cutting zone (i.e. interaction between tool and workpiece) is analyzed using Scanning Electron Microscopy (SEM). Material were selected for the purposes of the experiment - ELC Cr16Ni7Ti steel - which were then compared to $\mathrm{X} 2 \mathrm{Cr} 18 \mathrm{Ni} 8$ steel. The chemical composition of machined materials is reported in Table 4 . The microstructure of Cr16Ni7Ti steel is reported in Fig. 16.

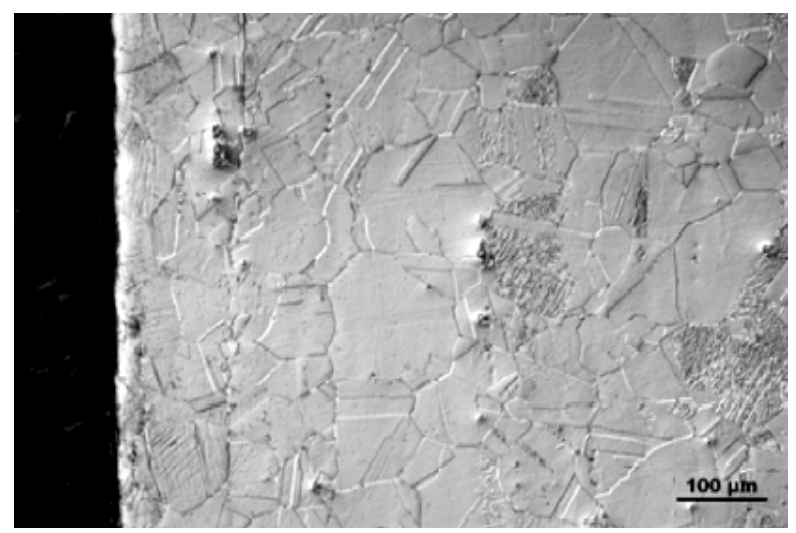

Fig. 16. Microstructure of X2Cr16Ni7Ti steel, etchant: Villela

\begin{tabular}{llllllll}
\hline $\mathrm{C}$ & $\mathrm{Cr}$ & $\mathrm{Ni}$ & $\mathrm{Mn}$ & $\mathrm{Si}$ & $\mathrm{P}$ & $\mathrm{Ti}$ & $\mathrm{S}$ \\
\hline 0.02 & 16.1 & 7.1 & 1.6 & 0.6 & 0.03 & 0.05 & 0.03 \\
\hline
\end{tabular}

Table 4. Chemical composition of stainless steels in wt [\%]

Cr18Ni8 steel microstructure contains larger quantities of complex carbides (as shown in Fig. 17.); these are generated along grain edges when compared to $\mathrm{X} 2 \mathrm{Cr} 16 \mathrm{Ni7Ti}$ steel. Due to the increased cutting speed of $60 \mathrm{~m}$ per min, drilling length was reduced to $1.6 \mathrm{~m}$. Tool life was reduced from 15 minutes to 5 minutes. When drilling $X 2 \mathrm{Cr} 18 \mathrm{Ni} 8$ steel at $30 \mathrm{~m}$ per min cutting speed, the following drilling length was achieved: $4.4 \mathrm{~m}$ (at feed $f=0.06 \mathrm{~mm}$ per rev.). Due to the increased cutting speed of $60 \mathrm{~m}$ per min, drilling length was reduced to $1.4 \mathrm{~m}$.

Tool life was reduced from 14 minutes to 3.6 minutes. When comparing the execution of holes for cutting tools into $\mathrm{X} 2 \mathrm{Cr} 16 \mathrm{Ni7Ti}$ steel, we observed that tool life was increased by $36 \%$ compared to $\mathrm{X} 2 \mathrm{Cr} 18 \mathrm{Ni} 8$ steel. The higher percentage of carbon does influence the increase of carbide formation, especially along grain edges (e.g. X2Cr16Ni7Ti steel); this fact has an impact on cutting tool lifes. By decreasing carbon content we eliminate carbide formation and therefore we increase cutting tool life.

Cutting tool damage follows a chain of events. After drilling holes the cutting edge was influenced by the formation of Built Up Edge-BUE, as shown in Fig.18. The built-up edge in the face and major flank area might be the result of adhesive wear close to the cutting edge. Holes were made in dry conditions in order to avoid any influence on experiment results with process media. Oxidation and diffusion (as wear mechanisms) were observed in 
deeper holes ( 3 to $5 \mathrm{xD}$ ). One of the basic causes of such mechanisms is the quantity of heat generated in the cutting area when holes are made (here one of the main causes is represented by the low heat conductivity of steel). If we apply a process medium, the above mentioned mechanisms would be substantially influenced - and in some cutting conditions they would be almost non-existent.

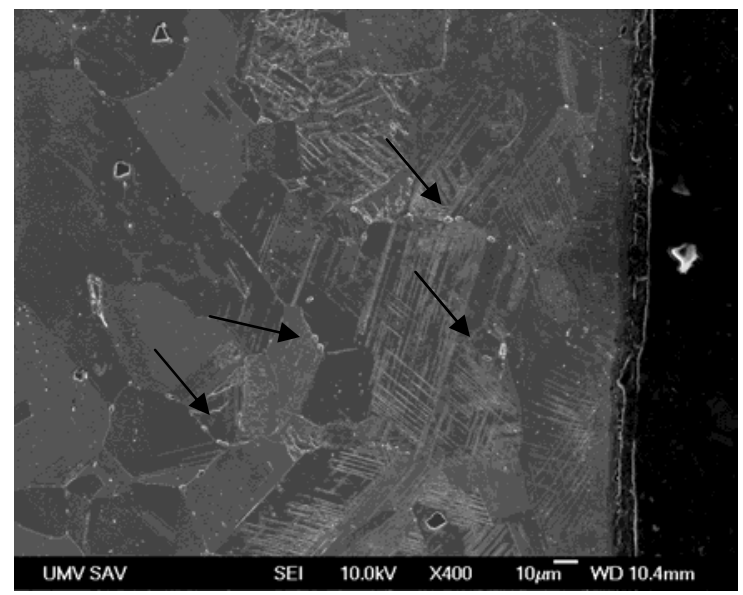

Fig. 17. Detail of $\mathrm{X} 2 \mathrm{Cr} 18 \mathrm{Ni} 8$ steel microstructure, generation of complex carbides along grain edges

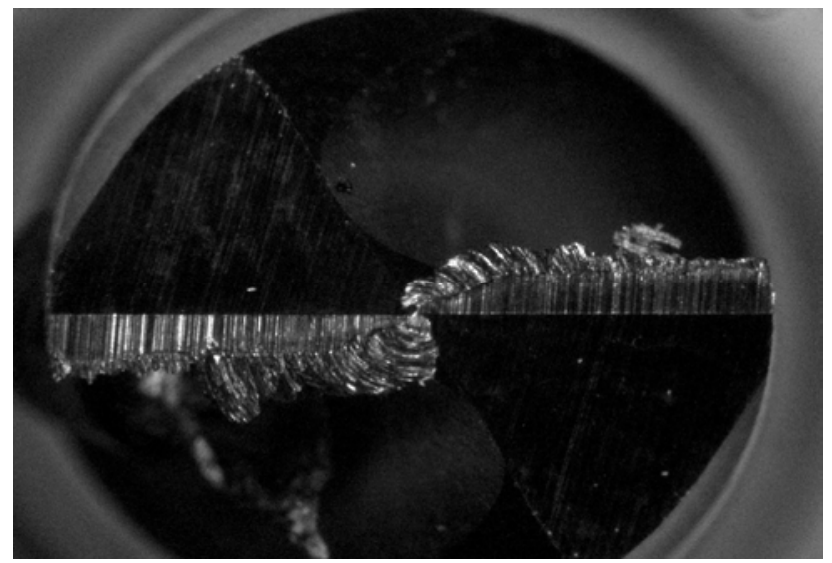

Fig. 18. Formation of built-up edges when drilling X2Cr16Ni7Ti steel

The tendency to generate built-up edges was more significant in the case of $\mathrm{X} 2 \mathrm{Cr} 18 \mathrm{Ni} 8$ steel than in the case of $\mathrm{X} 2 \mathrm{Cr} 16 \mathrm{Ni}$ Ti steel. One example of BUE formation for $\mathrm{X} 2 \mathrm{Cr} 16 \mathrm{Ni7Ti}$ steel during drilling followed these cutting conditions: cutting speed $v_{c}=45 \mathrm{~m}$ per min, feed $f=0.06$ $\mathrm{mm}$ per rev. and is shown in Fig.18. A cutting speed increase has an impact on BUE formation over the front area. By comparing the steels it was ascertained that in the case of $\mathrm{X} 2 \mathrm{Cr} 18 \mathrm{Ni} 8$ steel the corner was not worn (unlike $\mathrm{X} 2 \mathrm{Cr} 16 \mathrm{Ni}$ Ti steel). 
Fig.19 illustrates cutting zones. Qualitative and quantitative workpiece modifications do occur in the cutting zone. With regard to circumstances in the cutting zone, it is important to be aware of the input features of interacting objects (tool and workpiece) as well as of conditions influencing such interaction from the point of view of machining equipment. Output elements generated from the cutting: a workpiece with a machined surface and tool with possible cutting area damage.
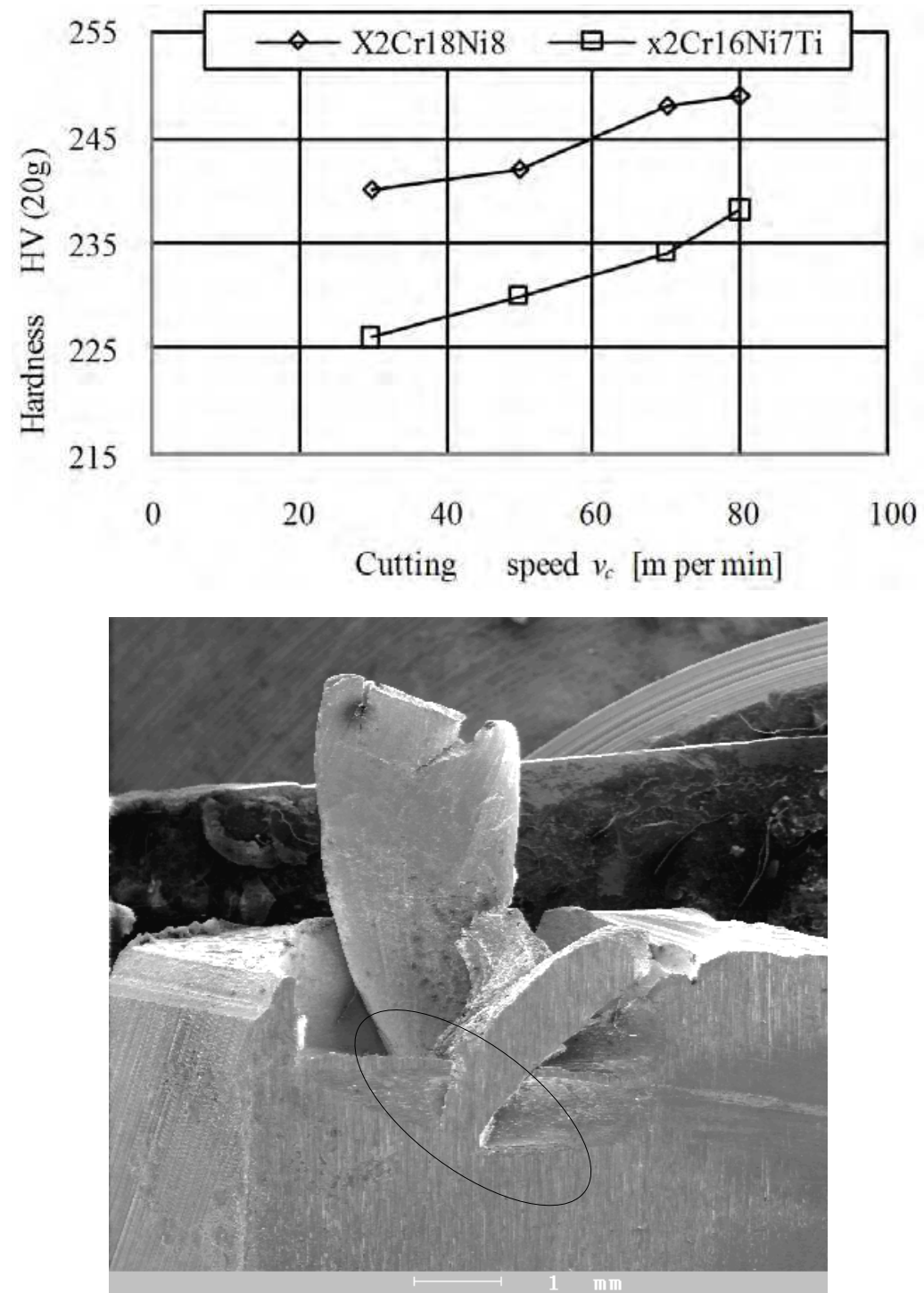

Fig. 19. Cutting zone - Drilling using a helical drill; interaction between the workpiece and tool cutting area 
Tool wear occurred continuously for $\mathrm{X} 2 \mathrm{Cr} 18 \mathrm{Ni} 8$ steel with the use of a cutting tool in dry machining. In this respect, at increasing cutting speeds tool plastic deformation takes place with gradual laminar flaking of the surface on the cutting tool and with destruction of the coat (frittering) over the front area; tool wear is influenced by the formation of built-up edges and by coat flaking. Stainless steels are influenced by charging due to intensive mechanical reinforcement during machining. The examination of reinforced surfaces can be carried out by measuring the micro-hardness of the bottom part of the fragment; indeed, the bottom part of the fragment can be considered as the most deformed fragment zone. The results of microhardness examination are reported in Fig. 20 and Fig. 21, these results are as follows:

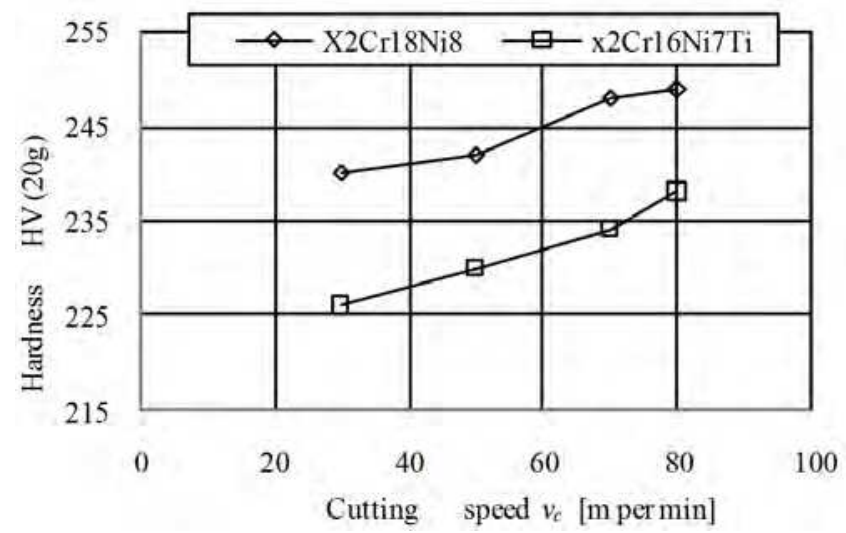

Fig. 20. Relation between machined workpiece micro-hardness and cutting speed when drilling holes into $\mathrm{X} 2 \mathrm{Cr} 18 \mathrm{Ni} 8$ and $\mathrm{X} 2 \mathrm{Cr} 16 \mathrm{Ni7Ti}$ steels - with feed $0.06 \mathrm{~mm}$ per rev.

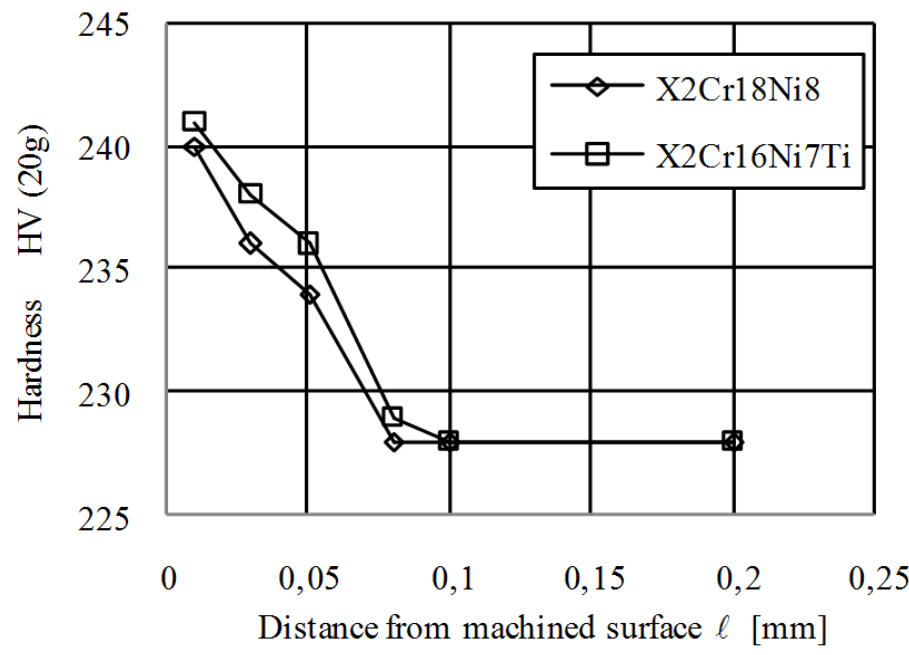

Fig. 21. Relation between machined workpiece micro-hardness and distance from machined surface when drilling holes into $\mathrm{X} 2 \mathrm{Cr} 18 \mathrm{Ni} 8$ and $\mathrm{X} 2 \mathrm{Cr} 16 \mathrm{Ni}$ Ti steels, at cutting speed $45 \mathrm{~m}$ per min, with feed $0.06 \mathrm{~mm}$ per rev 
- $\mathrm{X} 2 \mathrm{Cr} 18 \mathrm{Ni} 8$ steel: fragments are strongly deformed compared to $\mathrm{X} 2 \mathrm{Cr} 16 \mathrm{Ni}$ Ti steel. Austenite fragment, bottom part, $v_{c}=45 \mathrm{~m}$ per min, $305 \mathrm{HV}(20 \mathrm{~g})$ - if the bottom part of the fragment is measured: austenite $242 \mathrm{HV}(20 \mathrm{~g})$

- X2Cr16Ni7Ti steel: $v_{c}=45 \mathrm{~m}$ per min, austenite micro-hardness $228 \mathrm{HV}(20 \mathrm{~g})$ - if the bottom part of the fragment is measured: austenite $230 \mathrm{HV}(20 \mathrm{~g})$

- Result experiment was also analyzed application CAX system. On figures is painted the cutting zone-Fig.22, and themperature influence on the cutting tool and on the workpiece- Fig.23.

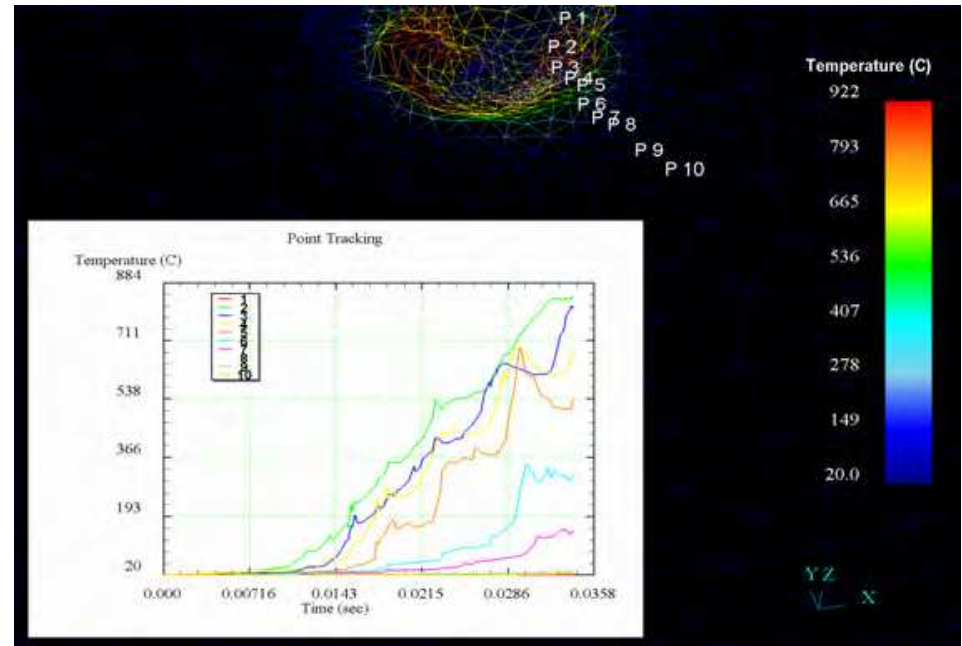

Fig. 22. The cutting zone-drilling of stainless steels $\mathrm{X} 2 \mathrm{Cr} 18 \mathrm{Ni} 8$

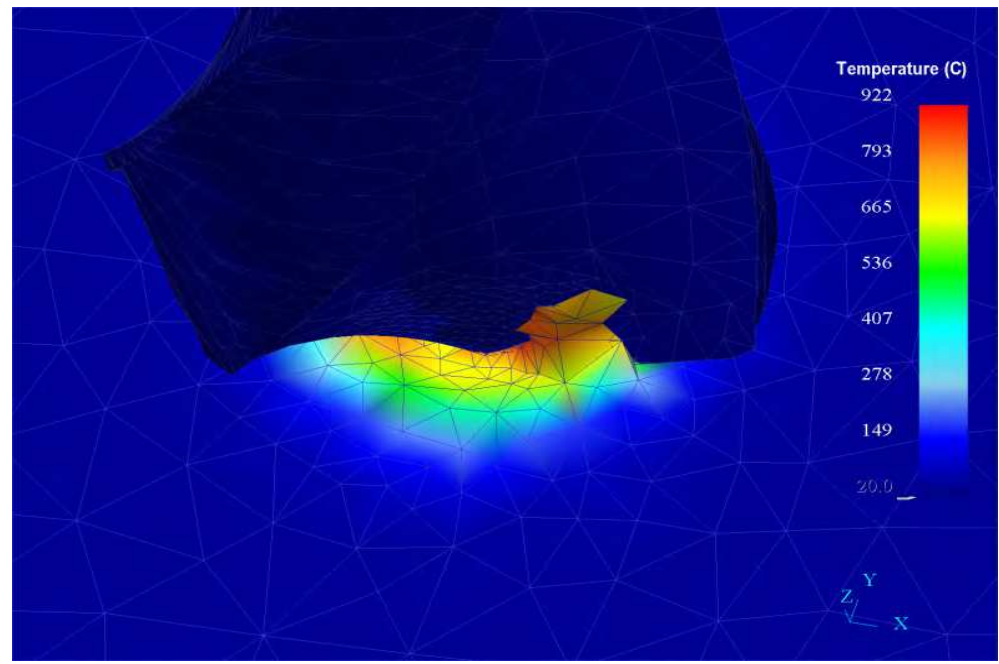

Fig. 23. Themperature influence - drilling of stainless steels $\mathrm{X} 2 \mathrm{Cr} 18 \mathrm{Ni} 8$, at cutting speed 45 $\mathrm{m}$ per min, with feed $0.06 \mathrm{~mm}$ per rev. 


\section{Conclusion}

The main objective of the development chapter is to provide information on the new stainless steels for application in food production facilities. Other important part of the experimental results for the design of technological processes of production and information on these steels for the machinability - four basic criteria: the machining process kinematics, dynamics of the machining process, chip formation and shaping and surface quality. Specifically, the orientation to the presentation the results of experience machining stainless steels with very low carbon called Extra Low Carbon Stainless Steels. Results of experiments in the laboratory at the university and real-life engineering firms have been verified by applying the CA-system simulation software applications based on the finite element method. The paper described verification of CAD systems applied by analysis of drilling tools. Analysis of tool life is very important for proces effectivity. Every tool is damaged in the process of cutting. Wear mechanisms are activated in the cutting zone during the interaction of the elements of the cutting edge of the tool and the workpiece, and under the influence of temperature, and by the fact that friction depends on the interaction of the clean metal surface between the front plate of the cutting edge of the tool and the chip. According to DIN 50321 we recognize four fundamental mechanisms of tool wear: adhesive wear, abrasive wear, fatigue wear, tribochemical reaction wear. The mechanism of wear means the synergistic effect of factors that create a change in matter, a change in volume, i.e., a change in cutting edge dimension.

\section{Acknowledgment}

The authors would like to thank in words the grant agency for supporting research work and cofinancing the projects: KEGA \#3/7166/2009 and VEGA \#1/0048/2010.

\section{References}

Davim, J. P. (2008). Machining - Fundamentals and Recent Advances. Springer, ISBN: 978-184800-212-8, Dordtrecht, Netherlands

Jurko, J. \& Zaborowski, T. (2009). Drilling - the cutting process. IBEN, ISBN 13-978-83-9251082-6, Gorzów Wlkp., Poland

Džupon, M.; Gajdoš, M.; Jurko, J. ; Ferdinandy, M. \& Jakubeczyová, D. (2011). Plastic Deformation Around Holes Drilled in Austenitic Steel 1.4301. Chemické listy, Vol.105, No. Special, (May 2011), pp. 606-608, ISSN 0009-2770

Jurko, J.; Panda, A. \& Gajdoš,M. (2011). Study of changes under the machined surface and accompanying phenomena in the cutting zone during drilling of stainless steels with low carbon content. Metalurgia, Vol.50, No.2, pp. 113-117, ISSN 0543-5846

Jurko, J.; Panda, A. \& Gajdoš,M. (2009). Accompanying phenomena in the cutting zone machinability during turning of stainless steels. International Journal Machining and Machinability of Materials, Vol.5, No.4, pp. 383-400, ISSN 1748-5711

Jurko, J.; Džupon, M.; Panda, A.; Gajdoš, M. \& Pandová, I. (2011). Deformation of Material Under the Machined Surface in the Manufacture of Drilling Holes in Austenitic Stainless Steel. Chemické listy, Vol.105, No. Special, (May 2011), pp. 600-602, ISSN 0009-2770 
Brinksmeier, E.W.; Reucher, A. \& Griet-Solter, J.(2008). Influence of characteristic material properties on machinability under high speed cutting. International Journal of Machining and Machinability of Materials, Vol.4, No.4, pp. 419-428, ISSN 1748-5711 


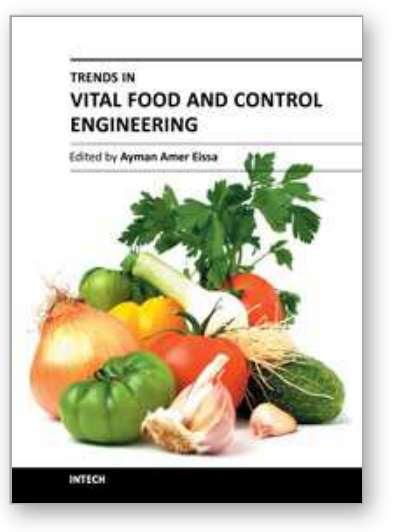

\author{
Trends in Vital Food and Control Engineering \\ Edited by Prof. Ayman Amer Eissa
}

ISBN 978-953-51-0449-0

Hard cover, 290 pages

Publisher InTech

Published online 05, April, 2012

Published in print edition April, 2012

This book is an example of a successful addition to the literature of bioengineering and processing control within the scientific world. The book is divided into twelve chapters covering: selected topics in food engineering, advances in food process engineering, food irradiation, food safety and quality, machine vision, control systems and economics processing. All chapters have been written by renowned professionals working in food engineering and related disciplines.

\title{
How to reference
}

In order to correctly reference this scholarly work, feel free to copy and paste the following:

Jozef Jurko, Anton Panda and Tadeusz Zaborowski (2012). Study of Evaluation Machinability of a Stainless Steels and Accompanying Phenomena in the Cutting Zone During Machining, Trends in Vital Food and Control Engineering, Prof. Ayman Amer Eissa (Ed.), ISBN: 978-953-51-0449-0, InTech, Available from:

$\mathrm{http}$ ://www.intechopen.com/books/trends-in-vital-food-and-control-engineering/study-of-evaluationmachinability-of-a-stainless-steels-and-accompanying-phenomena-in-the-cutting-zo

\section{INTECH}

open science | open minds

\section{InTech Europe}

University Campus STeP Ri

Slavka Krautzeka 83/A

51000 Rijeka, Croatia

Phone: +385 (51) 770447

Fax: +385 (51) 686166

www.intechopen.com

\section{InTech China}

Unit 405, Office Block, Hotel Equatorial Shanghai

No.65, Yan An Road (West), Shanghai, 200040, China

中国上海市延安西路65号上海国际贵都大饭店办公楼405单元

Phone: +86-21-62489820

Fax: $+86-21-62489821$ 
(C) 2012 The Author(s). Licensee IntechOpen. This is an open access article distributed under the terms of the Creative Commons Attribution 3.0 License, which permits unrestricted use, distribution, and reproduction in any medium, provided the original work is properly cited. 